Cornell University Law School Scholarship@Cornell Law: A Digital Repository

\title{
Coming to Grips with the Ethical Challenges for Capital Post-Conviction Representation Posed by Martinez v. Ryan
}

John H. Blume

CornellLaw School, jb94@cornell.edu

W. Bradley Wendel

Cornell Law School, bradley-wendel@lawschool.cornell.edu

Follow this and additional works at: http://scholarship.law.cornell.edu/facpub

Part of the Constitutional Law Commons, and the Legal Ethics and Professional Responsibility Commons

\section{Recommended Citation}

Blume, John H. and Wendel, W. Bradley, "Coming to Grips with the Ethical Challenges for Capital Post-Conviction Representation Posed by Martinez v. Ryan," 68 Florida Law Review 765-818 (2016)

This Article is brought to you for free and open access by the Faculty Scholarship at Scholarship@Cornell Law: A Digital Repository. It has been accepted for inclusion in Cornell Law Faculty Publications by an authorized administrator of Scholarship@Cornell Law: A Digital Repository. For more information, please contact jmp8@cornell.edu. 


\title{
COMING TO GRIPS WITH THE ETHICAL CHALLENGES FOR CAPITAL POST-CONVICTION REPRESENTATION POSED BY MARTINEZ V. RYAN
}

\author{
John H. Blume ${ }^{*}$ and W. Bradley Wendel ${ }^{* *}$
}

\begin{abstract}
In its groundbreaking decision in Martinez v. Ryan, 556 U.S. 1 (2012), the Supreme Court of the United States held that inadequate assistance of post-conviction counsel could be sufficient "cause" to excuse a procedural default thus allowing a federal court in habeas corpus proceedings to reach the merits of an otherwise barred claim that an inmate was deprived of his Sixth Amendment right to the effective assistance of counsel at trial. The upshot of Martinez is that, if state postconviction counsel unreasonably (and prejudicially) fails to raise a viable claim of ineffective assistance of trial counsel, then there is "cause" (and likely also prejudice), and thus a gateway to merits' review of the claim in federal habeas corpus proceedings. This is potentially a good thing for many habeas petitioners, but creates a serious and as-yet unappreciated ethical problem for federal habeas counsel who also served as state postconviction counsel. In capital post-conviction cases, the pre-Martinez preference and practice was for continuity of counsel from state to federal court. Now that ineffective representation in state post-conviction proceedings can serve as a basis for review of otherwise defaulted claims, however, a lawyer may be materially limited in her ability to provide ongoing representation by the client's interest in asserting an ineffectiveness claim.

Lawyers who practice in the area of civil litigation or transactional representation are familiar with these "prior work" conflicts and the solution to them, which is to obtain the informed consent of the affected client after full disclosure of the facts that give rise to the conflict and of the available alternatives. In the capital habeas context, however, the usual apparatus of professional responsibility law, including the informed consent doctrine and the potential of malpractice liability for mishandling a conflict, are ill-suited to dealing with the problem thrust upon petitioners' counsel by Martinez. Ironically, even though the tort doctrine of malpractice and the rules of professional conduct are both intended to

* Samuel F. Leibowitz Professor of Trial Techniques, Cornell Law School.

** Professor of Law, Cornell Law School. The author gratefully acknowledges the research funding provided by the Judge Albert Conway Memorial Fund for Legal Research, established by the William C. and Joyce C. O'Neil Charitable Trust to honor the memory of Judge Conway, Chief Judge of the New York State Court of Appeals from 1954 to 1959 and his son, Hewitt A. Conway, a member of the Cornell Law School Class of 1949. We are grateful to Bruce Green, Joe Margulies, Dana Remus, Keir Weyble, and participants in the Cornell Law School faculty retreat for helpful comments on this Article.
\end{abstract}


protect clients, the rules allow the possibly negligent lawyer to decide whether client protection requires disclosure and consent, or possibly withdrawal from representation. Given the significance of ineffective assistance of counsel in capital cases, however, this kind of selfmonitoring would be intolerable. Hence, the puzzle presented by Martinez, which recognizes the inability of lawyers to self-monitor, but fails to provide a mechanism for ensuring that the client's rights are adequately protected.

This Article suggests, therefore, that petitioners' counsel cannot bear the sole responsibility for solving the Martinez dilemma. The other systemic and repeat players-States' attorneys and judges-also have to do their part. After all, it is the invocation of procedural defenses in an effort to preclude merits' review of the habeas petitioner's federal constitutional claims that creates the procedural morass we have described. This in turn leads to both inefficient litigation and unjust results. Thus, in most instances, if attorneys for the state agreed-either on their own or after being "leaned on" by the court-to waive procedural default and allow the court to proceed to the merits, then litigation would proceed expeditiously and without the ethical taint of potential and actual conflicts of interest. If the claims are not bona fide, they will be rejected. On the other hand, if the issues not previously raised are in fact meritorious, then there are no true "losers" unless one believes that death sentences resulting from a trial infected with prejudicial constitutional error should be carried out. Without some cooperative solution, courts will be faced with motions for substitution of counsel or the appointment of independent counsel to evaluate the performance of state postconviction counsel; state attorneys general will have to deal with the possibility of further delay while the conflict issue is adjudicated. Thus, the tentatively hopeful conclusion to this exploration of the conundrum of Martinez is that the institutional actors with a stake in procedures and outcomes will work together to create an avenue for credible claims of inadequate state post-conviction representation to be investigated competently, for clients to be fully informed and involved in the decisionmaking process, and ultimately the client's wishes respected.

INTRODUCTION

I. THE SiXTH AMENDMENT AND THE LAW OF

ProfESSIONAL RESPONSIBILITY...

II. "PRIOR WORK" CONFLICTS IN THEIR NATURAL

ENVIRONMENT

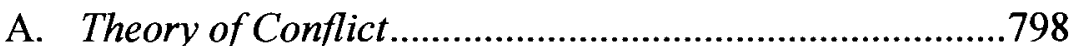

B. Waivability. 802 
C. Informed Consent and Its Limitations .............................803

D. Clients with Diminished Decision-Making

Capacity.

III. Why CRiminal Defense, AND Particularly

CAPITAL DEFENSE, IS DIFFERENT.

CONCLUSION

\section{INTRODUCTION}

In its groundbreaking decision in Martinez $v$. Ryan, ${ }^{1}$ the Supreme Court held that inadequate assistance of state post-conviction counsel could satisfy the "cause" requirement necessary to allow a federal court in habeas corpus proceedings to reach the merits of an otherwise procedurally barred claim alleging that an inmate was deprived of his Sixth Amendment right to the effective assistance of counsel at trial. ${ }^{2}$ That was quite a mouthful, but what does it actually mean? This Article first attempts to "unpack" the terms, its content, and then explores the ethical issues the Court's decision poses for attorneys representing prisoners in federal habeas corpus actions.

A person charged with a crime in state or federal court has a Sixth Amendment right to the assistance of counsel. ${ }^{3}$ If the defendant is indigent, then under most circumstances, she is entitled to courtappointed counsel. ${ }^{4} \mathrm{~A}$ defendant is not just entitled to a lawyer; the lawyer must be competent, or in the Supreme Court's terms, the defendant (theoretically) has the right to the "effective assistance of counsel." In most jurisdictions, a defendant who pleads guilty or is

1. 132 S. Ct. 1309 (2012).

2. Id. at 1319-20 ("[A]n attorney's negligence in a postconviction proceeding does not establish cause ....").

3. The Sixth Amendment provides, in relevant part, that "[i]n all criminal prosecutions, the accused shall enjoy the right to ... have the Assistance of Counsel for his defence." U.S. CONST. amend. VI.

4. Gideon v. Wainwright, 372 U.S. 335, 340, 345 (1963). In Gideon, the Supreme Court held that indigent defendants are entitled to court-appointed counsel in criminal cases but did not specify the precise scope of the right. Id. Subsequently, in Scott v. Illinois, the Court held that a court cannot sentence a criminal defendant to a term of actual imprisonment "unless the State has afforded him the right to assistance of appointed counsel." 440 U.S. 367, 373-74 (1979). A suspended sentence is considered to be "actual" imprisonment. See Alabama v. Shelton, 535 U.S. $654,657-58,674$ (2002).

5. Strickland v. Washington, 466 U.S. 668, 686 (1984) (quoting McMann v. Richardson, 397 U.S. 759, 771 n.14 (1970)). A lawyer is not "effective" for Sixth Amendment purposes if the attorney's performance was both "deficient" (i.e., objectively unreasonable) and "prejudicial" (i.e., there is a reasonable probability that had the lawyer performed adequately, the result of the proceeding would have been different). See id. at 687-88, 694. This Article uses the word 
convicted at trial and wishes to assert a claim of ineffective assistance of counsel must do so in state post-conviction proceedings. ${ }^{6}$ Every state has, by one name or another, a post-conviction procedure for persons adjudicated guilty of a crime to present additional evidence as to why the court should vacate the conviction or sentence. ${ }^{7}$ That is where, for the most part, defendants assert claims of ineffective or inadequate assistance of counsel. ${ }^{8}$ If the inmate is unsuccessful in the state courts, she can ask the federal courts, via the "great writ" of federal habeas corpus, ${ }^{9}$ to review federal constitutional challenges to the conviction or sentence, including a Sixth Amendment claim of ineffective assistance of trial counsel. ${ }^{10}$ However, among other obstacles to a federal court vacating a state court conviction, if the defendant did not present a federal claim to the state courts during state post-conviction proceedings, then the federal courts will not entertain the issue due to principles of comity and federalism, or more simply, respect for state court judgments and the finality of

"theoretically" advisedly. The Strickland standard is widely-and correctly-criticized for tolerating grossly incompetent representation. See, e.g., John H. Blume \& Sheri Lynn Johnson, Gideon Exceptionalism?, 122 YALE L.J. 2126, 2138-39 (2013).

6. See generally John H. Blume, An Introduction to Post-conviction Remedies, Practice and Procedure in South Carolina, 45 S.C. L. REv. 235, 239, 242 (1994) (illustrating that a postconviction proceeding can pertain to the right of counsel).

7. See, e.g., id. at 238, 245 (tracing the history and development of South Carolina's state post-conviction procedures).

8. The writ of habeas corpus is still sometimes used in South Carolina to challenge the validity of a conviction or sentence. See id. at 262. The Sixth Amendment does not require states to appoint counsel in state post-conviction proceedings (but many do); however, an inmate has the right - if he can afford to do so-to retain counsel. See U.S. CONST. amend. VI (providing an accused the right "to the Assistance of Counsel for his defence" in criminal prosecutions). But see Blume \& Johnson, supra note 5, at 2138 (noting the difficulties for defendants alleging deprivation of the Sixth Amendment right to the effective assistance of counsel). For the most part, state courts push adjudication of ineffective assistance claims to post-conviction proceedings because, by and large, a court cannot decide such assertions of attorney incompetence simply by reviewing the "cold" trial record. See Eve Brensike Primus, Effective Trial Counsel After Martinez v. Ryan: Focusing on the Adequacies of State Procedures, 122 YALE L.J. 2604, 2609 (2013) ("Because ineffective assistance of trial counsel claims are often predicated on what trial attorneys failed to do, they frequently require extrarecord development."). Additional evidence is often needed, such as counsel's reasons for pursuing (or not pursuing) certain courses of action or lines of defense. See id.

9. See Fay v. Noia, 372 U.S. 391, 401 (1963).

10. See 28 U.S.C. $\$ 2254$ (b) (2012) (mandating when a court may grant an application for a writ of habeas corpus). Before seeking federal review, the inmate must first present to the state courts any alleged federal constitutional defects in her conviction or sentence. Id. This is referred to as the exhaustion-of-state-remedies requirement. See Rose v. Lundy, 455 U.S. 509, 513, 516 (1982) (discussing the development and scope of the "exhaustion doctrine"). The general purpose of the rule is to provide - as a matter of comity and federalism-state courts with the first opportunity to consider claims that call into question the constitutional validity of one of its criminal convictions. $I d$. at 518 . 
convictions. ${ }^{11}$ In the habeas corpus taxonomy, the claim is generally considered to be "procedurally defaulted" because it was not raised in the right court at the right time. ${ }^{12}$ Procedural default precludes a merits' review of the claim by the federal courts unless the inmate can show "cause" and "prejudice" for failing to present the claim to the state courts or a manifest miscarriage of justice (i.e., actual innocence of the offense).$^{13}$ "Cause" is generally a reason not attributable to the inmate for failing to raise the claim earlier, ${ }^{14}$ and "prejudice" in this context means that the failure to raise the claim earlier (or adequately) had an effect on the prior proceedings that may have changed the outcome of the trial. ${ }^{15}$

Prior to Martinez, the Court had rejected arguments that failings of state post-conviction counsel, even shockingly poor representation, could serve as "cause" for failing to raise a claim properly in state court. ${ }^{16}$ The Court rejected these arguments primarily because it had concluded that there was no Sixth Amendment right to counsel in state or federal post-

11. See id. at 518-19 (holding that a total exhaustion rule will encourage state prisoners to first seek full relief, including relief for federal claims, from the state court).

12. See Wainwright v. Sykes, 433 U.S. 72, 83-85 (1977). Other common examples of state procedural defaults include failing to lodge a contemporaneous objection at trial and failing to raise a properly preserved claim on direct appeal. See id. at 83 n.8 (citing Henry v. Mississippi, 379 U.S. 443 (1965)); Gray v. Netherland, 518 U.S. 152, 161 (1996).

13. Gray, 518 U.S. at 162; Wainwright, 433 U.S. at $90-91$. It is actually a bit more complicated than what this Article presented above. The claim could be "unexhausted" (and not procedurally defaulted) if the state courts allow a state prisoner to file more than one application for post-conviction relief. The exhaustion-of-state-remedies doctrine requires inmates who file a federal habeas petition to first present claims of constitutional error to the state courts. 28 U.S.C. $\S 2254$ (2012); Rose, 455 U.S. at 516, 518 ("[O]ne court should defer action on causes properly within its jurisdiction until the courts of another sovereignty ... have had an opportunity to pass upon the matter." (quoting Darr v. Burford, 339 U.S. 200, 204 (1950))). But because most states have a "one bite at the apple" rule for persons seeking post-conviction relief, in most instances, the claim will be "exhausted" because the inmate does not have a currently available state remedy and procedurally defaulted because the defendant did not present the claim to the state courts in post-conviction proceedings. See, e.g., Williams v. State, 98 So. 3d 484, 487 (Miss. Ct. App. 2012) (quoting Dobbs v. State, 18 So. 3d 259, 298 (Miss. Ct. App. 2009)).

14. Murray v. Carrier, 477 U.S. 478, 488 (1986) (explaining that the defendant must ususually establish "cause" by showing that an "objective factor external to the defense impeded counsel's efforts").

15. See Strickler v. Greene, 527 U.S. 263, 289, 291 (1999) (finding that the petitioner did not show prejudice, which would have excused a procedural default, because the prosecution's failure to disclose favorable information did not give rise to a reasonable probability of a different outcome at trial).

16. See, e.g., Coleman v. Thompson, 501 U.S. 722, 727, 750, 757 (1991) (holding that postconviction counsel's negligent failure to file a timely notice of appeal in a capital post-conviction proceeding, which led to the procedural default of all of the death-sentenced inmate's claims, failed to satisfy the "cause" requirement). 
conviction proceedings. ${ }^{17}$ Thus, if there is no right to counsel, then, $a$ fortiori, there is no right to the effective assistance of counsel. ${ }^{18}$ The Court then fell back to the default principle that lawyers are generally regarded as the client's agent. ${ }^{19}$ Therefore, counsel's mistakes are deemed attributable to the defendant ${ }^{20}$ Although the Court did not make this reasoning explicit, it could have relied upon the role assigned by rules of professional conduct to defense counsel to monitor his own performance, ensure that there are no conflicts of interest, and do whatever additional work is necessary to acquire the skill required to render competent performance. ${ }^{21}$

But in Martinez, the Court changed tack and recognized for the first time that-as a matter of equity-inadequate assistance of postconviction counsel could, under some circumstances, be "cause" for failing to raise claims in state post-conviction proceedings. ${ }^{22}$ Under what circumstances though? First, the exception applies only to claims of ineffective assistance of trial counsel. ${ }^{23}$ If state post-conviction counsel fails to identify and present other types of common post-conviction claims, e.g., prosecutorial misconduct in failing to disclose exculpatory information or juror misconduct-no matter how meritorious the issue might be-Martinez's equitable exception does not apply. ${ }^{24}$ Second, the

17. Id. at 754-55. Every state has state post-conviction procedures, although federal law does not require them. See Blume, supra note 6, at 241, $258 \mathrm{n} .169$ (explaining how state courts chose to expand the scope of post-conviction proceedings in response to the Supreme Court's expansion of the availability of habeas corpus). The basis of the Court's rejection of a constitutional right to counsel post-trial lies in the language of the Sixth Amendment, which guarantees counsel to an "accused" for his "defence." U.S. ConST. amend. VI. In the Court's view, after an adjudication of guilt, either by trial or plea, a defendant is no longer an "accused" person presenting a defense. Rather, he is a convicted person attempting to overturn a presumptively lawful determination of guilt. See Ross v. Moffitt, 417 U.S. 600, 610-11 (1974).

18. Coleman, 501 U.S. at 752.

19. See id. at 753-54.

20. See id.

21. MODEL RULES OF PROF'L CONDUCT r. 6.2 cmt. 2 (AM. BAR ASS'N 2015).

22. 132 S. Ct. 1309,1320 (2012).

23. See id. at 1317-18.

24. Justice Kennedy was quite explicit about this. Id. at 1317 (noting that effective assistance of counsel at trial is a "bedrock principle in our justice system"). However, as the dissent noted, there is no principled basis for limiting the exception to trial-level ineffective assistance of counsel claims. See id. at 1321 (Scalia, J., dissenting). For example, claims that the prosecution withheld exculpatory, material information (commonly referred to as Brady claims) are also generally not available on direct appeal because the suppression of evidence has not yet come to light. See, e.g., Banks v. Dretke, 540 U.S. 668, 675, 693, 698 (2004) (granting a new penalty phase to a death-sentenced inmate based on the suppression of information discovered for the first time in federal habeas corpus proceedings). The same is also true in many cases involving juror misconduct. See, e.g., Williams v. Taylor, 529 U.S. 420, 440 (2000) (finding that there was "cause" in a state post-conviction proceeding for petitioner's failure to raise the claim that a juror 
exception only applies to jurisdictions that, either explicitly or as a matter of practice, require claims of ineffective assistance of trial counsel to be asserted in state post-conviction proceedings. ${ }^{25}$ In the Court's view, if a defendant cannot challenge trial counsel's competency on direct appeal-a proceeding in which she would have the right to the effective assistance of appellate counsel - then the state collateral review process constitutes the first opportunity for review. ${ }^{26}$ Thus, this process is akin to an appeal "as of right," in which the defendant is guaranteed the right to the effective assistance of counsel. ${ }^{27}$

Returning to the bottom line, if state post-conviction counsel unreasonably (and prejudicially) fails to raise a viable claim of ineffective assistance of trial counsel, then there is "cause" (and likely "prejudice") - and thus a gateway to a merits' review of the claim in federal habeas corpus proceedings. So far, so good. But, in many instances, state post-conviction counsel is also federal habeas corpus counsel. In fact, in capital post-conviction cases, the pre-Martinez preference and practice was for continuity of counsel from state to federal court. $^{28}$ For obvious reasons, having state post-conviction counsel represent the inmate in federal court was believed to promote higher quality and more cost-effective representation. State post-conviction counsel will also be familiar with the trial and post-conviction records and the issues in the case (and thus will not need additional time to "get up to speed"), but will also - in most instances - have a positive working relationship with the client. And, given the paucity of funding for counsel (and experts) in many states in state collateral proceedings, ${ }^{29}$ state post-

lied on voir dire when evidence was not discovered until completion of direct appeal and state collateral review).

25. See Trevino v. Thaler, 133 S. Ct. 1911, 1918, 1921 (2013) (finding that Texas law, as a matter of course, requires defendants to assert ineffective assistance of trial counsel claims in state post-conviction proceedings because the "Texas procedural system . . . does not offer most defendants a meaningful opportunity to present a claim of ineffective assistance of trial counsel on direct appeal").

26. See Martinez, 132 S. Ct. at 1315-16.

27. See id. at 1319. While the Court analogized post-conviction proceedings in this context to an appeal of right, it did not hold that there is a constitutional right to counsel in post-conviction proceedings; instead, the Court relied upon principles of equity to create the exception for otherwise procedurally barred claims. Id. at 1319-20. Presumably, it did so in an attempt to "cabin" the exception - limit it to ineffective assistance of trial counsel claims, which would have been impossible had the Court recognized a constitutional right to counsel in post-conviction proceedings. See id. Perhaps it also did so to limit the fiscal burden on the states that would follow from creating a constitutional right to counsel.

28. See Guide to the Appointment and Compensation of Counsel Under the Criminal Justice Act, section *.28. See 7A Admin. OfFice of the U.S. COURTS, Guide to Judiciary Policy $\$ 220.25$ (c) (2015), http://www.uscourts.gov/file/2793/download.

29. Benjamin H. Barton \& Sephanos Bibas, Triaging Appointed-Counsel Funding and Pro 
conviction counsel may have taken the case through the state collateral appeals system hoping to recoup some of their investment in federal court given the relatively better compensation system for counsel in federal habeas corpus cases. ${ }^{30}$

Yet this common and preferred practice developed in a legal regime in which inadequate assistance of state post-conviction counsel was of no significance. That is no longer true; it is now a means of having federal courts adjudicate procedurally defaulted claims, and thus - in any given case - could literally be the difference between a client rotting in prison or being released and, in some instances, lives or dies. ${ }^{31}$ Given this shift in the relevance of the quality of state post-conviction representation, what are the implications of Martinez's recognition of inadequate assistance of post-conviction counsel as "cause" for a procedural default for cases currently pending in (or about to enter) federal habeas corpus proceedings where counsel who are appointed (or seek to be appointed) represented the inmate in state post-conviction proceedings? The question becomes more complicated when considered in light of a defense attorney's obligations under both the Sixth Amendment's right to effective assistance of counsel and the rules of professional conduct generally applicable to all lawyers. ${ }^{32}$ Although criminal defense lawyers

Se Access to Justice, 160 U. PENN. L. Rev. 967, 972-73 (2012); see also Ira P. Robbins, Toward a More Just and Effective System of Review in State Death Penalty Cases, 40 AM. U. L. REv. 1, 76-77 (1990) (noting that many states pay attorneys virtually nothing to defend in capital cases).

30. It is not always the case that state post-conviction counsel also represents the inmate in federal habeas corpus proceedings. Sometimes, the client may want new counsel, or the lawyer may conclude she is not competent to represent the client in federal court given the complexity of federal habeas corpus. In other cases, the state collateral appeals lawyer may work for a state defender organization that cannot appear in federal court, or the jurisdiction may have a unit in a Federal Public Defender's Office (generally referred to as Capital Habeas Units) that is staffed and funded to represent persons only in federal habeas proceedings. See, e.g., Capital Habeas Unit, FeD. PUB. DeFENDER: DISTRICT ARIz.. http://www.fpdaz.org/\#!capital-habeas-unit/bgm64 (last visited Feb. 10, 2016). But, prevailing national practice, especially in active death penalty jurisdictions such as Alabama, Texas, South Carolina, and Virginia, is for continuity of representation from state to federal court.

31. For example, the State of Virgina executed Roger Coleman after denying him federal habeas review because his state post-conviction attorneys filed a notice of appeal three days late. See Subcommittee on Civil and Constitutional Rights, Innocence and the Death Penalty: Assessing the Danger of Mistaken Executions, DEATH PENALTY INFO. CTR. (Oct. 21, 1993), http:// www.deathpenaltyinfo.org/innocence-and-death-penalty-assessing-dangermistaken-executions.

32. All lawyers are subject to professional discipline, with sanctions ranging from a private reprimand up to suspension from practice or disbarment, which courts of the state of the lawyer's admission mete out. See Charles W. WOLfRAM, MODERN LEGAL ETHICS $\S 3.2$, at $82, \S 3.5$, at 118 (student ed. 1986). The power to impose discipline is theoretically reposed in the state's supreme court, although investigation and prosecution of disciplinary matters is generally delegated to an agency of the court. See 1 Geoffrey C. HazARD, JR. ET AL., THE LAW OF LAWYERING $\S 1.16,30-31$ (3d ed. Supp. 2014). Discipline is based on evidence of a violation of 
and prosecutors quite understandably tend to think first in terms of constitutional principles, they must also comply with the lawyer disciplinary rules of the state of their admission. Under these rules, a state post-conviction lawyer who failed - unreasonably and with prejudiceto raise an ineffective assistance of counsel claim with respect to trialcourt representation likely has a material-limitation conflict of interest under state versions of the concurrent conflicts rule. ${ }^{33}$

Lawyers who practice in the area of civil litigation or transactional representation are familiar with "prior work" conflicts and the solution to them, which is to obtain the informed consent of the affected client after full disclosure of the facts giving rise to the conflict and the available alternatives. ${ }^{34}$ As this Article discusses below, however, the standard response within the law of professional responsibility-relying on the informed consent doctrine-is ill adapted to the circumstances of criminal defense, particularly capital defense representation. ${ }^{35}$

Martinez further complicates the standard approach by significantly increasing the stakes around the evaluation of an attorney's own malpractice and potential conflicts of interest. In the ordinary case, an attorney is constantly making judgment calls, and maybe some of them are mistakes. Most of these mistakes, however, will not end up amounting to much, and even if they do, they are unlikely to subject the attorney to liability for malpractice. Only in the unusual event of a mistake that creates a substantial likelihood of subjecting the attorney to civil liability will there be a conflict of interest requiring the attorney to obtain the client's informed consent. Significantly, the rules of professional conduct allow attorneys to make this judgment call as well. Attorneys decide when they have made a mistake sufficiently serious to constitute malpractice, when potential malpractice constitutes a conflict of interest, whether that conflict is waivable, and what disclosure is adequate as a ground for the client's informed consent. ${ }^{36}$ Ironically, even though the

state rules of professional conduct. This Article uses the terms "rules of professional conduct" and "disciplinary rules" interchangeably here (with the latter term invoking the familiar "subject to discipline" standard used on the Multistate Professional Responsibility Exam).

33. See Model Rules of Prof'L Conduct r. 1.7(a)(2) (AM. BAR Ass'N 2015) ("[A] lawyer shall not represent a client if the representation involves a concurrent conflict of interest. A concurrent conflict of interest exists if: ... there is a significant risk that the representation of one or more clients will be materially limited . . . by a personal interest of the lawyer.").

34. See id. r. 1.0(e) (defining "informed consent" as "the agreement by a person to a proposed course of conduct after the lawyer has communicated adequate information and explanation about the material risks of and reasonably available alternatives to the proposed course of conduct").

35. See infra Section II.C.

36. See MODEL RULES OF PROF'L CONDUCT r. 1.7, cmt. 2 (giving the lawyer responsibility for determining the existence of a conflict, whether it is waivable, and what disclosure is required 
tort doctrine of malpractice and the rules of professional conduct are both intended to protect clients, the rules allow the possibly negligent lawyer to decide whether client protection requires disclosure and consent, or possibly withdrawal from representation. ${ }^{37}$ Given the significance of ineffective assistance of counsel in capital cases, however, this kind of self-monitoring would be intolerable. Hence, the puzzle presented by Martinez, which recognizes the inability of lawyers to self-monitor, but fails to provide a mechanism for ensuring that the client's rights are adequately protected.

The difficulty of the Martinez problem is illustrated by a recent case decided by the Supreme Court, Christeson v. Roper. ${ }^{38}$ In Christeson, counsel appointed to represent a death row inmate missed the filing deadline for their client's federal habeas petition, leading to its dismissal as untimely under the Antiterrorism and Effective Death Penalty Act of 1996 (AEDPA).$^{39}$ Although the Court did not rule on the issue, counsel's inexplicable errors, including not only miscalculating the limitations period but also failing to communicate with their client after being appointed at a particularly time-critical period, were likely the types of "serious ... attorney misconduct" that could equitably toll the statute of limitations. ${ }^{40}$ For the attorneys to argue for equitable tolling, however, would be to admit their own incompetence, creating a conflict between the attorneys' duty to provide competent and diligent representation and their interest in preserving their professional reputations. ${ }^{41}$ The conflict created by their prior incompetence rendered the attorneys unable to represent the petitioner in the ongoing litigation, involving as it would the attempt to equitably toll the AEDPA statute of limitations. ${ }^{42}$ But Christeson only highlights the Martinez problem; it does not point toward

in order to satisfy the informed consent standard). We are grateful to Bruce Green for emphasizing this aspect of the usual relationship between malpractice and conflicts of interest.

37. See Model Rules of PROF'L ConduCt r. $1.7 \mathrm{cmt} .4$.

38. 135 S. Ct. 891 (2015).

39. Id. at 892 .

40. Id. at 892, 894 (quoting Holland v. Florida, 560 U.S. 631, 651-52 (2010)).

41. Id. at 894 . The Court gives the attorneys some credit for recognizing this conflict, but the attorneys actually missed the point completely. They noted that a hearing on whether they had abandoned their client (and thus created grounds for equitable tolling) would involve them as essential witnesses. Id. This would involve a violation of the advocate-witness rule. See MODEL RULES OF PROF'L Conduct r. 3.7(a). The advocate-witness rule, which is really aimed at preventing jury confusion and is in any event waivable if disqualification would work substantial hardship on the client, id. r. 3.7(a)(3) cmt. 2, was the least of the attorneys' problems. A substantial likelihood that the attorneys would make arguments that "manifestly served their own professional and reputational interests," to the direct detriment to their client's interests, is a serious and non-waivable conflict under Rule 1.7(a)(1) of the Model Rules of Professional Conduct. Christeson, 135 S. Ct. at 895.

42. Christeson, 135 S. Ct. at 895. 
a solution. The attorneys' conflict of interest came to the attention of the district court through the efforts of independent lawyers who had examined the case and immediately spotted the conflict. ${ }^{43}$ If this second pair of lawyers had not injected themselves into the case (as there is currently no mechanism to ensure the involvement of conflict-free substitute counsel), the petitioner would have lost the opportunity to argue for equitable tolling and file a federal habeas petition.

This Article's analysis begins in Part I by attempting to disentangle the relationship between the Sixth Amendment's guarantee of the effective assistance of counsel and the rules of professional conduct adopted by state courts for the regulation of lawyers in that state. Courts, including the Supreme Court, sometimes talk as though a lawyer's obligations under the rules of professional conduct are some kind of lower-order law that is less important than the Sixth Amendment. While of course the Constitution is the supreme law of the land and state courts may not impose duties on counsel that contravene it, lawyers quite understandably are concerned with complying with all the standards that govern their professional conduct. As a criminal procedure and a professional responsibility scholar, respectively, we speak somewhat different languages when talking about the duties of a criminal defense attorney-but this Article indicates that these perspectives must be integrated when considering the Martinez dilemma. Accordingly, Part II takes a step back from the specific context of state and federal postconviction representation and looks at prior-work conflicts of interest more generally, as they would be handled under the state rules of professional conduct. In an ideal case, as noted above, it would be possible for a lawyer to handle this problem by providing full disclosure to the client and obtaining the client's informed consent to continued representation. ${ }^{44}$ As is so often the case, however, "death is different," 45 and there are features of capital defense representation that make the problem of prior-work conflicts much more difficult to deal with. The insidious nature of entrusting an attorney to self-monitor conflicts of interest, even when there are reasons to question the attorney's capacity for exercising independent judgment, may be tolerable in ordinary civil malpractice cases and is certainly tolerable in those frequently litigated cases involving sophisticated, repeat-player clients. But in the representation of individual, disempowered clients - often suffering from mental illness or cognitive disabilities - there must be an alternative to the usual approach. Finally, Part III considers the contextual features that make conflicts of interest particularly difficult in federal habeas

43. See id. at 892-93.

44. See supra text accompanying note 37.

45. See, e.g., Simmons v. South Carolina, 512 U.S. 154, 185 (1994) (Scalia, J., dissenting). 
representation and suggests some approaches to resolving Martinez conflicts in the inherently non-ideal world of capital litigation.

\section{The SiXTh AMENDMENT AND the LAw OF Professional RESPONSIBILITY}

The norms governing criminal defense lawyering, including postconviction representation, are an amalgam of several different bodies of law that stand in an uneasy relationship to one another. However, they all create duties on the part of lawyers, despite the tendency of some lawyers to ignore them. In particular, criminal defense lawyers accustomed to thinking in terms of the Sixth Amendment's right to the effective assistance of counsel may sometimes overlook the disciplinary rules governing conflicts of interest. Civil litigators and transactional lawyers live and die by the conflicts rules because they can make the difference between the ability to accept a long-lasting, lucrative representation of a client and the obligation to decline such representation. Litigating motions to disqualify is an expensive headache even if the motion is ultimately unsuccessful, so lawyers spend a great deal of energy on prevention strategies designed to head off the possibility of disqualification. Criminal defense lawyers, by contrast, tend to analyze conflicts exclusively in terms of the Sixth Amendment right to effective assistance of counsel, which has the relatively unusual remedy of a new trial, as seen in Sixth Amendment cases such as Cuyler v. Sullivan ${ }^{46}$ and Mickens $v$. Taylor ${ }^{47}$ While all lawyers are in principle subject to state rules of professional conduct, many criminal defense lawyers overlook these professional responsibilities and focus only on the Sixth Amendment standards.

While there is plenty of ignorance of the law governing lawyers to go around, among both civil and criminal litigators, many civil lawyers at least practice in large law firms with in-house counsel to advise them on the technical aspects of conflicts of interest. ${ }^{48}$ These firms are also generally very sensitive to the possibility of civil liability for malpractice or breach of fiduciary duty, and they are often subject to malpractice insurance guidelines that limit potential liability exposure. Criminal defense lawyers, by contrast, may work in large public defender

46. 446 U.S. 335, 342-43 (1980). Sullivan, in turn, was based on earlier cases such as Holloway v. Arkansas, 435 U.S. 475, 484 (1978), and Glasser v. United States, 315 U.S. 60, 76 (1942). See Sullivan, 446 U.S. at 349-50. Sullivan, Holloway, and Glasser differ from the nowstandard Sixth Amendment framework subsequently established in Strickland v. Washington, 466 U.S. 668, 697 (1984), in that Strickland requires an additional showing of prejudice.

47. 535 U.S. 162,164 (2002).

48. Elizabeth Chambliss, The Scope of In-Firm Privilege, 80 NOTRE DAME L. REV. 1721, 1721 (2005). 
organizations but are frequently solo or small-firm practitioners and therefore do not have the same kind of compliance infrastructure. ${ }^{49}$ However, they do consider potential claims for ineffective assistance of counsel, which becomes the primary framework for understanding conflicts of interest in criminal defense representation. Courts also sometimes overlook the duties imposed by the rules of professional conduct, perhaps unaware that a defense lawyer who raises a conflict of interest is not playing games or stalling for time but trying in good faith to comply with her obligations under the disciplinary rules. This Part analyzes the Martinez dilemma by considering the relationship between the federal and state systems of regulating the professional conduct of lawyers.

It is admirable for defense lawyers to aim at representation that satisfies the minimum guarantees of the Constitution, but it is a serious mistake, analytically and as a matter of ethical lawyering, to fail to consider duties that go beyond the constitutional floor established by the ineffective assistance of counsel cases. Concerns over the remedy that follows from a finding of ineffective assistance pervade many Sixth Amendment ineffective assistance of counsel cases; if there is a finding of ineffective assistance of counsel, the court must hold a new trial, this : time with representation free from constitutional error ${ }^{50}$ Courts are. reluctant to set too high a threshold for the minimum standard of representation, fearing a flood of new trials would follow. Lawyers may therefore infer erroneously that they are obligated to do no more than avoid a conflict that would lead to a new trial. As the Supreme Court has emphasized repeatedly, however, another reason for not, constitutionalizing the law of professional responsibility is that the legal profession is an independent, self-governing institution. ${ }^{51}$ If defense lawyers are thankful that federal courts applying the Sixth Amendment are not micromanaging their conduct in representing clients, they must understand the basis for that deference, which is the courts' expectation that lawyers will comply with norms established by the profession itself.

49. This is true even if the defense lawyer is a public defender in a large office. Due to large caseloads and systemic under-funding of the indigent defense, even large defender organizations do not have anything approaching the conflict-compliance procedures used in the civil litigation context. See, e.g., Barton \& Bibas, supra note 29, at 972-77.

50. See Restatement (Third) OF the LaW Governing Lawyers $§ 6(12)$ (AM. LaW InSt. 2000) (listing "granting a new trial" as a potential remedy for a lawyer's breach of a duty to a client).

51. See, e.g., Nix v. Whiteside, 475 U.S. 157, 165 (1986) (holding that constitutionalizing the Rules of Professional Conduct would be "intrud[ing] into the state's proper authority to define and apply the standards of professional conduct applicable to those it admits to practice in its courts"). 
As discussed below, ${ }^{52}$ those norms are embodied in state rules of professional conduct, based in every jurisdiction (except California) on the American Bar Association's (ABA) Model Rules. ${ }^{53}$ They apply to all lawyers, regardless of the context in which they practice, and not only provide the grounds for potential professional discipline (disbarment, suspension, reprimand, etc.), but also state the profession's own vision of what constitutes ethical conduct. ${ }^{54}$

Courts, in turn, need to be aware of the mess they make when they fail to consider the interaction among seemingly separate, but in fact related, sources of professional guidance. For example, the Court in Mickens created considerable uncertainty over the application of the presumption of prejudice in Cuyler to conflicts of interest other than concurrentrepresentation conflicts. Writing for the Court, Justice Antonin Scalia observed:

The purpose of our Holloway and [Cuyler] exceptions from the ordinary requirements of Strickland, however, is not to enforce the Canons of Legal Ethics, but to apply needed prophylaxis in situations where Strickland itself is evidently inadequate to assure vindication of the defendant's Sixth Amendment right to counsel. In resolving this case on the grounds on which it was presented to us, we do not rule upon the need for the Sullivan prophylaxis in cases of successive representation..$^{55}$

Never mind that the "Canons of Legal Ethics" have not been in effect in any jurisdiction since the adoption of disciplinary rules based on the ABA's Model Code of Professional Responsibility (Model Code) in the early $1970 \mathrm{~s}^{56}$ Justice Scalia blurred the distinction between the

52. See infra p. 17 and note 84.

53. See infra note 84.

54. Because the Model Rules are intended to apply to all lawyers, further specification of duties may be required in specialized areas of practice. Under the auspices of the ABA, committees of experienced lawyers, judges, and law professors produce commentary or guidelines that show how the general duties stated in the Model Rules apply in particular contexts. See, e.g., Lawrence J. Fox, Capital Guidelines and Ethical Duties: Mutually Reinforcing Responsibilities, 36 Hofstra L. REv. 775, 776 (2008) (explaining how the ABA's capital defense counsel guidelines are derived from duties stated in the Model Rules).

55. Mickens v. Taylor, 535 U.S. 162, 176 (4th Cir. 2002) (citation omitted).

56. See HAZARD, supra note $32, \S 1.11$, at 1-21. The ABA promulgated the Canons of Ethics in 1908 . Id. $\S 1.10$, at 1-20. They had only precatory effect, except to the extent they overlapped with the common law governing lawyers. Id. $\S 1.10$, at 1-20 to -21 . "[T] re-promulgated by the courts as law." Id. The most charitable interpretation of Justice Scalia's dismissal of the rules of professional conduct, supported by his reference to the Canons, is that he was thinking of this long-outdated list of aspirations. It is perfectly clear today, however, that the 
successive-representation conflicts rule, which itself is a prophylactic rule designed to protect the client's reasonable expectation of the former lawyer's loyalty and confidentiality ${ }^{57}$ and the prophylactic application of the presumption of prejudice. It may be that there was no Sixth Amendment violation because the conflict of interest had no effect on the representation. ${ }^{58}$ That does not mean, however, that Mickens' lawyer did not have a conflict of interest. He had previously represented the victim in an unrelated criminal matter ${ }^{59}$ and, as a result, almost certainly learned confidential information that he was professionally obligated to keep secret. He also may have felt a residual sense of loyalty to his former client, which might have made it more difficult to pursue certain avenues in defense of his present client. The effect on the representation may not have risen to the level of an "actual conflict of interest [that] adversely affected [the] lawyer's performance," as required to trigger the presumption of prejudice under Cuyler ${ }^{60}$ (although there are strong arguments that it did), but it may nevertheless have been a sufficiently serious interference with the lawyer's duties to require him to withdraw from the representation and permit the defendant to secure substitute counsel.

All lawyers are subject to discipline for violations of the rules of conduct adopted in the state or states in which they are admitted to practice. ${ }^{61}$ State courts enact these rules pursuant to the inherent power of the state judiciary to regulate the practice of law in the territorial jurisdiction of the state. ${ }^{62}$ They not only represent the views of the

Model Rules are "set forth in the manner of a true code - mandatory conduct rules, without the 'softening' addition of hortatory provisions that were meant to inspire rather than coerce." Id. $\S 1.12$, at $1-21$.

57. See Model Rules of Prof'L Conduct r. $1.9 \mathrm{cmt}$. 1 (AM. BAR Ass'N 2015).

58. See Mickens, 535 U.S. at 179 (Kennedy, J., concurring). Specifically, Mickens involved a defense attorney assigned to represent a minor on assault and concealed-weapon charges. Id. at 164 (majority opinion). The appointed attorney met with the client one time for between fifteen and thirty minutes. Id. Within the week, the minor client was murdered. Id. at 164-65. The minor defendant's initial lawyer was subsequently appointed as defense counsel for the man accused of the forcible sodomy and murder of his former client. $I d$.

59. See id. at 164 .

60. See Cuyler v. Sullivan, 446 U.S. 335, 348 (1980).

61. See Model Rules of Prof'l Conduct r. 8.5(a).

62. See Restatement (ThiRd) OF THE Law Governing Lawyers $\S 1 \mathrm{cmt}$. b (AM. LAW INST. 2000). The Restatement is a significant source of authority in the law of professional responsibility because it attempts to unify the principles expressed in the state rules of professional conduct with generally applicable norms of tort, contract, agency, procedure, and other law that bear on the conduct of lawyers. For example, provisions respecting conflicts of interest take into account not only cases imposing discipline for representing a client while subject to a conflict, but also cases involving disqualification by a court from the representation of a client due to conflicts of interest, which is technically an aspect of a different inherent power of a tribunal- 
organized profession concerning the ethical obligations of lawyers, but also are enforceable through state disciplinary procedures. ${ }^{63}$ As the Supreme Court explained in Strickland, ${ }^{64}$ defense lawyers are also obligated by their clients' Sixth Amendment rights to provide effective assistance of counsel. ${ }^{65} \mathrm{~A}$ lawyer owes the client a duty of objectively reasonable performance, as measured by prevailing professional norms. ${ }^{66}$ Justice Sandra Day O'Connor, writing for the Court in Strickland, suggested that rules of professional conduct adopted by state courts are one source of guidance for determining the content of these norms. ${ }^{67}$ At the same time, however, she cautioned against a per se equivalence between the constitutionally guaranteed effective assistance of counsel and conduct that was mandatory under state disciplinary rules:

No particular set of detailed rules for counsel's conduct can satisfactorily take account of the variety of circumstances faced by defense counsel or the range of legitimate decisions regarding how best to represent a criminal defendant. Any such set of rules would interfere with the constitutionally protected independence of counsel and restrict the wide latitude counsel must have in making tactical decisions. ${ }^{68}$

The ideal of the bar as an independent institution, to which Justice O'Connor appeals, has deep historical roots, ${ }^{69}$ and it is understandable that at the time she authored Strickland she did not wish to involve the Court in establishing detailed guidelines for competent representation. However, the language in numerous ineffective assistance of counsel

the power to regulate the conduct of litigation in that court. See id. $\S 1 \mathrm{cmt}$. c; WOLFRAM, supra note $32, \S 2.2 .4$, at 31-32 (distinguishing a trial court's inherent authority to regulate the conduct of lawyers appearing before the tribunal from the inherent power of the judiciary more broadly to regulate the legal profession). Disqualification is an equitable remedy imposed by courts to protect the integrity of its proceedings. Because it is an equitable remedy, however, and because not all participants in a litigated matter may have standing to raise a conflict of interest in a motion to disqualify, disqualification cases may diverge in important ways from cases imposing professional discipline or, for that matter, from cases involving lawsuits by clients for malpractice or breach of fiduciary duty arising out of a conflict-burdened representation. The Restatement does an admirable job of unifying these diverse sources of normative authority into a relatively coherent body of law - the law governing lawyers.

63. RESTATEMENT (THIRD) OF THE LAW GOVERNING LAWYERS $\S 5(1)$.

64. 466 U.S. $668,685(1984)$.

65. Id.

66. Id. at 688 .

67. Id.

68. Id. at $688-89$.

69. See Robert W. Gordon, The Independence of Lawyers, 68 B.U. L. REv. 1, 6 (1988) (chronicling the historical meaning of professional independence and how lawyers have "pursued their vision of independence in their practices"). 
cases decided since Strickland has created unnecessary confusion with respect to the relationship between the rules of professional conduct and the constitutional minimum for competent performance by defense counsel. In particular, some Justices seem to have contributed to an attitude among judges and lawyers that the state rules of professional conduct are inferior to other sources of guidance for lawyers. At the very least, the Court has not been consistent in the attitude it expresses toward state disciplinary rules, which may have had the unfortunate result of tacitly suggesting to defense lawyers that the rules are unimportant.

Consider Nix $v$. Whiteside. ${ }^{70}$ In that case, after the defendant suddenly changed his account of how a killing took place, the defense lawyer told his client that if the client insisted on taking the stand and testifying falsely, it would be counsel's duty to inform the court that he felt his client was committing perjury and to seek to withdraw. ${ }^{71}$ The client subsequently filed a petition for a writ of habeas corpus claiming that his lawyer's refusal to allow him to testify to the second version of events deprived him of the effective assistance of counsel. ${ }^{72}$ Applying the performance prong of Strickland, the Court reiterated that prevailing professional norms are the yardstick for measuring competent representation. ${ }^{73}$ Significantly, it distinguished between what state rules of professional conduct might require, on the one hand, and what the Sixth Amendment might require on the other:

Under the Strickland standard, breach of an ethical standard does not necessarily make out a denial of the Sixth Amendment guarantee of assistance of counsel. When examining attorney conduct, a court must be careful not to narrow the wide range of conduct acceptable under the Sixth Amendment so restrictively as to constitutionalize particular standards of professional conduct and thereby intrude into the state's proper authority to define and apply the standards of professional conduct applicable to those it admits to practice in its courts. ${ }^{74}$

70. 475 U.S. 157 (1986).

71. Id. at 161 .

72. Id. at 162 .

73. Id. at 165 .

74. Id. The Court's use of the term "ethical standard" here, while familiar enough, is potentially misleading because state rules of professional conduct are legally enforceable rules of positive law, not merely statements of what a good lawyer ought to do. See LIAM MURPHY, WHAT MAKES LAW: AN INTRODUCTION TO THE PHILOSOPHY OF LAW 23-24 (2014) (defining positive law as that which can be ascertained without moral deliberation about what the law ought to be). There are many different ways to understand the word "ethics." The ABA Model Code distinguished between statements of best practices that were not intended to constitute enforceable rules, called 
The Court then set out a summary of the duties of counsel, as a matter of the state rules of professional conduct, for when a criminal defendant announces the intention to testify falsely. ${ }^{75}$ Here is where the Justices' discussion of the applicable standards of professional conduct subtly diverge, showing the importance of the Court's attitude toward the disciplinary rules.

Chief Justice Warren Burger, writing for the majority, stated that "an attorney's revelation of his client's perjury to the court is a professionally responsible and acceptable response to the conduct of a client who has actually given perjured testimony." 76 That would be true today. The Model Rules arguably permit the lawyer's conduct in Whiteside-sternly admonishing the client to tell the truth and informing him of counsel's duties to inform the court and withdraw from representation in the event of perjury. ${ }^{77}$ The defense lawyer's conduct would therefore be within

Ethical Considerations (ECs), and enforceable, black-letter rules, called Disciplinary Rules (DRs), stating minimum standards of conduct, the violation of which would subject an attorney to discipline. See Model Code of Prof'l Responsibility Preliminary Statement (Am. Bar Ass'N 1980). This distinction corresponds with what Professor Lon Fuller called the "morality of aspiration" and the "morality of duty," respectively. See LON L. FULLER, THE MORALITY OF LAW 5-6 (1964). As Professor David Luban points out, this is an idiosyncratic use of the idea of morality. See DAVID LUBAN, Natural Law as Professional Ethics: A Reading of Fuller, in LEGAL. ETHICS AND HUMAN DigNiTY 99, 105 (2007). Philosophers generally use "ethics" and "morality" interchangeably, although a few philosophers have attempted to argue for a distinction. See, e.g., BERNARD WILLIAMS, ETHICS AND THE LIMITS OF PHILOSOPHY 6 (1985). The important distinction for the purposes of the ethics and conduct of lawyers is between (1) norms that take the form of enforceable standards, potentially subjecting lawyers to some form of legal sanctions, including professional discipline (disbarment, suspension, reprimand, etc.), civil liability, or a finding of constitutional ineffectiveness, and (2) norms that make rational demands on any moral agent, including those acting in a professional capacity, and thus establish standards for the evaluation of conduct as right or wrong irrespective of law. For example, one might contend that it is wrong in ethical terms to dedicate one's skill and training as a lawyer to prevent the extradition to Israel of an accused concentration camp guard, while conceding that there is no legal prohibition on doing so. See Monroe H. Freedman, Must You Be the Devil's Advocate?, Legal Times, Aug. 23, 1993, at 19, reprinted in MONROE H. FrEEDMAN \& ABBE SMITH, UNDERSTANDING LAWYERS' EтHICS app. A, at 371 (4th ed. 2010). While the term "legal ethics" is often understood as equivalent to the law governing lawyers or the state rules of professional conduct, to preserve analytical clarity, this Article does not use it in this way.

75. Whiteside, 475 U.S. at 166-68.

76. $I d$. at 170.

77. See MOdel Rules of PROF'L CONDUCt r. $3.3 \mathrm{cmt}$. 6 (AM. BAR ASS'N 2015) ("If a lawyer knows that the client intends to testify falsely ... the lawyer should seek to persuade the client [and] ... [i]f the persuasion is ineffective ... the lawyer must refuse to offer the false evidence."). The lawyer may have misapplied the rules, however, by concluding that the client intended to testify falsely, based on the client changing his story and saying that, based on other cases that argued self defense, "If I don't say I saw a gun, I'm dead." Whiteside, 475 U.S. at 161. The duties imposed on lawyers with respect to false testimony are triggered only when the lawyer knows the testimony will be false. MODEL RULES OF PROF'L CONDUCT r. $3.3 \mathrm{cmt}$. 6 . Knowledge is a defined 
prevailing norms of professional conduct under the Model Rules, which are now the basis for the rules of professional conduct in forty-nine states and the District of Columbia. ${ }^{78}$ Complicating the analysis, however, Chief Justice Burger apparently misunderstood the Model Code, a version of which was then in effect in Iowa. ${ }^{79}$ The Model Code handled the problem of perjury in an awkward, roundabout way. In contrast with the Model Rules, which have a specific rule for witness perjury and an explicit priority of duties between candor to the tribunal and maintaining client confidences, ${ }^{80}$ the Model Code treated the professional response to client perjury as an instance of the general problem of assisting client crimes and of disclosing confidential information to prevent future crimes. ${ }^{81}$ Because it handled the problem in this way, it created ambiguity

term in the Model Rules and refers to actual (subjective) knowledge. Id. r. 1.0(f). Court decisions occasionally underscore that knowledge really does mean knowledge. See, e.g., State v. McDowell, 681 N.W.2d 500, 518-19 (Wis. 2004) (defining knowledge of intended perjury as knowledge "based on the client's expressed admission of intent to testify untruthfully") (emphasis added).

78. See Ctr. For Prof'l Responsibility, Model Rules of Professional Conduct, http://www.americanbar.org/groups/professional_responsibility/publications/model_rules_of_pr ofessional_conduct.html (last visited Feb. 12, 2016). California remains a holdout, with a hybrid system based on its own rules of professional conduct and various provisions of the California Business \& Professions Code. See California Rules of Prof'L Conduct r. 1-100(A) (State BAR OF CAL. 2014).

79. See Whiteside, 475 U.S. at 167-68. Additionally, lawyers sometimes misunderstand the lack of authority of the ABA Model Code and Model Rules. The word "model" is not used for nothing. Committees of the ABA, consisting of lawyers, judges, and academics, propose rules of professional conduct that states can be adopt, but the ABA models have no force until the highest court of a state adopts them. See ResTatemENT (THIRD) OF THE LAW GOVERNING LAWYERS $\S 1$ cmt. b (AM. LAW INST. 2000). Professional responsibility scholars may speak informally of duties under the Model Rules, but it is well established that the binding rules are those adopted by the state's highest court. See id. This is not merely a pedantic distinction, as state courts may vary the content of the rules from the ABA versions. As a general rule, the more controversial an issue is in the law of lawyering, the more state-by-state variation can be expected.

80. See MOdel Rules OF Prof'L CONDUCT r. 3.3(c) (stating that the duties in Rule 3.3 apply even where compliance would require disclosure of information protected by the duty of confidentiality in Rule 1.6). The rule requires the lawyer to refuse to offer evidence known to be false and to take "reasonable remedial measures" if the lawyer later comes to learn of the falsity of evidence previously offered. Id. r. 3.3(a)(3). Those remedial measures include first trying to persuade the witness not to testify falsely or to correct previously given false testimony but may ultimately include disclosure to the tribunal of the perjury. $I d$. r. $3.3 \mathrm{cmt}$. [10].

81. See Model Code of Prof'L Responsibility DR 7-102(A)(4) (AM. Bar Ass'N 1980) ("[A] lawyer shall not ... [k]nowingly use perjured testimony"). As compared with the Model Rules, this provision is troublesome because it does not provide guidance to a lawyer confronted with a client, such as Emanuel Whiteside, who is apparently determined to testify falsely. The attorney's duty of confidentiality would cover the communication from the client to the lawyer in which the client expresses an intention to lie on the stand. In Whiteside, the client stated that he believed that if he did not testify to having seen a gun, he would not be successful in claiming self-defense. 475 U.S. at 161. What should the lawyer do in that case? The Model Code did allow 
concerning the permissibility of revealing false testimony after the fact, as permitted by the Model Rules. ${ }^{82}$ Chief Justice Burger seemed unimpressed with this technical distinction-which of course would be highly significant to a lawyer seeking to avoid professional disciplineand relied instead on the proposition that a lawyer's permissible actions are limited to "legitimate, lawful conduct compatible with the very nature of a trial as a search for truth."

Justice William Brennan wrote separately to emphasize that the decision established only the proposition that if a lawyer complies with the state rules of professional conduct regarding client perjury, then the lawyer's representation could not be constitutionally ineffective. ${ }^{84}$ The case does not stand for the rule that a lawyer is constitutionally required to dissuade a client from committing perjury, disclose it to the court, or take any other specific steps if he knows a client intends to testify falsely. ${ }^{85}$ Justice Brennan reminded lawyers that "the Court's essay regarding what constitutes the correct response to a criminal client's suggestion that he will perjure himself is pure discourse without force of law." 86

a lawyer to disclose "[t]he intention of his client to commit a crime and the information necessary to prevent the crime." MODEL CODE OF PROF'L RESPONSIBILITY DR 4-101(C)(3). Because perjury is a crime, Whiteside's lawyer would have been permitted to disclose the client's stated intention to testify falsely. The lawyer would also have been permitted, and perhaps required, to withdraw if the continued representation would result in a violation of a disciplinary rule or would constitute an illegal course of conduct; perjury, a crime, would satisfy those requirements. See id. DR 2$110(\mathrm{~B})(2),(\mathrm{C})(1)(\mathrm{b}),(\mathrm{C})(2)$.

82. On its face the Model Code seemed to require, not merely to permit, after-the-fact revelation of client perjury. See MODEL CODE OF PROF'L RESPONSIBILITY DR 7-102(B)(1) ("A lawyer who receives information clearly establishing that . . [h]is client has, in the course of representation, perpetrated a fraud upon a person or tribunal shall promptly call upon his client to rectify the same, and if his client refuses or is unable to do so, he shall reveal the fraud to the affected person or tribunal, except when the information is protected as a privileged communication."). Note the last clause - "except when . . protected as a privileged communication." Lawyer knowledge of client perjury is likely to come from a confidential attorney-client communication and thus be within the protection of the attorney-client privilege. But the ABA Committee on Professional Ethics, in Formal Opinion 341 (1975), stated that the "except" clause should be read more broadly, as emcompassing both "secrets" (that is, information protected by the duty of confidentiality) as well as attorney-client privileged communications. What DR 7-102(B)(1) seemed to create as a retrospective duty to disclose client perjury was thus completely undercut by the "except" clause and its interpretation by the ABA Committee. See Monroe H. Freedman \& ABbe Smith, Understanding LaWyers' Ethics 133 44 (2d ed. 2002) (recounting this history).

83. Whiteside, 475 U.S. at 166.

84. See id. at 177 (Brennan, J., concurring).

85. See id.

86. Id. 
It is important to see that Whiteside does not stand for the principle that there is no relationship between the state rules of professional conduct and the Sixth Amendment. It is true that not all violations of the rules of professional conduct give rise to a claim for ineffective assistance of counsel, just as not all conduct in violation of the rules gives rise to a malpractice claim. It could be the case, however, consistent with Whiteside, that a violation of the state disciplinary rules also violates the performance prong of Strickland. That is an open question after Strickland and Whiteside. What is remarkable about Whiteside, considered in the context of subsequent Supreme Court cases, is how seriously some of the Justices took the state rules of professional conduct. Justice Burger's majority opinion traced the history of the rule on client perjury from the 1908 Canons of Ethics, through the 1969 Model Code, to the 1983 Model Rules, noting that the disciplinary rules had always imposed some duty on counsel to avoid introducing perjured testimony or other false evidence. ${ }^{87}$ The majority analyzed a lawyer's duty under the Model Rules and Model Code and stated without hedging that "under no circumstance may a lawyer either advocate or passively tolerate a client's giving false testimony." 88 The Court seems to have been saying that the disciplinary rules - the then-existing Iowa Code of Professional Responsibility - are consistent with the defense lawyer's duties under the Sixth Amendment, and therefore there can be no constitutional ineffectiveness in a representation in which the lawyer follows rules that apparently coincide with a plausible constitutional vision of the defense lawyer's role. ${ }^{89}$

Justice Harry Blackmun was, if anything, more deferential to state rules of professional conduct. ${ }^{90} \mathrm{He}$ saw the problem of the proper professional response to client perjury as a difficult one, calling for the exercise of judgment and consideration of a number of factors that are likely to differ case-by-case. ${ }^{91}$ A "blanket rule" adopted by the Court would unnecessarily limit the flexibility states have to adopt rules that reflect differing approaches to the perjury problem. ${ }^{92}$ For that reason, Justice Blackmun thought the primary source of norms governing the conduct of criminal defense lawyers ought to be the state disciplinary rules. ${ }^{93}$ Federalism concerns substantially drove Justice Blackmun's opinion, leading him to conclude that the Sixth Amendment is, in a sense,

87. Id. at 166-68 (majority opinion).

88. Id. at 171 .

89. See id. at 175 .

90. See id. at 189-90 (Blackmun, J., concurring).

91. Id. at $188-89$.

92. Id at 189.

93. See id. at $189-90$. 
subordinated to the inherent authority of state courts to regulate the legal profession. ${ }^{94}$

In subsequent cases, however, some Justices have sought to drive a wedge between the Sixth Amendment and other norms of professional conduct, implicitly subordinating the latter. For example, in Holland $v$. Florida, ${ }^{95}$ a lawyer was appointed to represent a death row inmate in filing a federal habeas corpus petition. ${ }^{96}$ The lawyer failed to file the petition within the one-year statute of limitations prescribed by the AEDPA.$^{97}$ The Court held that the statute was equitably tolled due to the extraordinary circumstance of the lawyer's failure to satisfy applicable professional standards of care ${ }^{98}$ As a matter of state law, the lawyer's misconduct went far beyond "garden variety" negligence and constituted a violation of fundamental standards of professional responsibility. ${ }^{99}$ Ironically, Justice Scalia, who was ordinarily inclined to give states room to regulate without excessive intrusion by federal courts, ${ }^{100}$ dissented in Holland, arguing that the majority had failed to identify a standard under which the lawyer's performance was grossly negligent. ${ }^{101}$ Justice Scalia stated, "The only thing the Court offers that approaches substantive instruction is its implicit approval of 'fundamental canons of professional responsibility,' articulated by an ad hoc group of legal-ethicist amici consisting mainly of professors of that least analytically rigorous and hence most subjective of law-school subjects, legal ethics.'

The sources relied upon by the Court majority-the Model Rules and the Restatement (Third) of the Law Governing Lawyers, which were in effect in Florida and applicable to the lawyer's representation of the petitioner ${ }^{103}$-self-evidently do not state subjective standards. A subjective standard would approve of a lawyer's conduct as long as he

94. See id.

95. 560 U.S. $631(2010)$

96. Id. at $635-66$.

97. Id. at 635,643 (quoting 28 U.S.C. $\S 2244(\mathrm{~d})(1)-(2)$ (2012))

98. Id. at 649 .

99. Id. at 652-53 (citing Brief of Legal Ethics Professors et al. as Amici Curiae in Support of Petitioner, Holland v. Florida, 560 U.S. 631 (2010) (No. 09-5327), 2009 WL 5177143). One of the authors of this Article was a signatory on the amicus brief.

100. See, e.g., State Farm Mut. Auto. Ins. Co. v. Campbell, 538 U.S. 408, 429 (2003) (Scalia, J., dissenting) (stating that the Due Process Clause does not provide substantive protection against excessive punitive damages awards); United States v. Virginia, 518 U.S. 515, 576-78 (1996) (Scalia, J., dissenting) (urging deference to state policy in favor of single-sex education at Virginia Military Institute); BMW of N. Am., Inc. v. Gore, 517 U.S. 559, 598-99 (1996) (Scalia, J., dissenting) (stating that the Due Process Clause is not a "secret repository of substantive guarantees against 'unfaimess'").

101. Holland, 560 U.S. at 670 (Scalia, J., dissenting).

102. Id.

103. Id. at $652-53$ (majority opinion). 
"acted honestly and bona fide to the best of his own judgment." 104 An objective standard, on the other hand, requires lawyers to measure up to the standards set by others within the profession. These standards are objective to the extent there is something other than the lawyer's own best efforts that can be used to determine whether the lawyer's performance was adequate. ${ }^{105}$ Indeed, the brief brushed aside by Justice Scalia discussed objective duties of competence, communication, and loyalty grounded in tort, agency, and constitutional law, as well as the rules of professional conduct. ${ }^{106}$

Justice Scalia knew the difference between objective and subjective standards, and he was perfectly well acquainted with the use of custom to establish standards of care in other contexts, so his dismissal reflected either a substantive disagreement with the content of the standards established by the rules or an annoyance that state courts have adopted standards of professional conduct that require lawyers to take their fiduciary duties to clients seriously. But the opinion also reflects a reverse of the subordination described by Justice Blackmun in Whiteside. Rather than federal courts deferring to state disciplinary rules to preserve flexibility and a variety of responses to a problem of professional ethics; Justice Scalia wished to oust the authority of state courts and disciplinary rules and to replace them with a blanket federal constitutional rule that licensed gross negligence by defense counsel. The trouble with this reverse-subordination move is that it is inconsistent with the principle in Strickland that the legal profession's prevailing norms set the standard for effective assistance of counsel. Justice O'Connor's opinion in Strickland cautioned courts not to create rigid guidelines for defense lawyers and also warned against judging in hindsight, but it did so while emphasizing that courts should look to the profession to flesh out the required standard of care:

104. Cf. Vaughan v. Menlove (1837), 132 Eng. Rep. 490, 493; 3 Bing. (N.C.) 468, 474-75 (rejecting this approach to duties of reasonable care in tort law).

105. Every first-year torts student is familiar with the distinction drawn by then-Judge Oliver Wendell Holmes between a person doing the best he is able and the standard of conduct that the law requires:

If . . a man is born hasty and awkward, is always having accidents and hurting himself or his neighbors, no doubt his congenital defects will be allowed for in the courts of Heaven, but his slips are no less troublesome to his neighbors than if they sprang from guilty neglect. His neighbors accordingly require him, at his proper peril, to come up to their standard....

Oliver Wendell Holmes, JR., The Common LaW 108 (1881).

106. See Brief of Legal Ethics Professors et al. as Amici Curiae in Support of Petitioner, supra note 99. 
Prevailing norms of practice as reflected in American Bar Association standards and the like are guides to determining what is reasonable, but they are only guides. No particular set of detailed rules for counsel's conduct can satisfactorily take account of the variety of circumstances faced by defense counsel or the range of legitimate decisions regarding how best to represent a criminal defendant. Any such set of rules would interfere with the constitutionally protected independence of counsel and restrict the wide latitude counsel must have in making tactical decisions. Indeed, the existence of detailed guidelines for representation could distract counsel from the overriding mission of vigorous advocacy of the defendant's cause. ${ }^{107}$

It is clear that the Strickland analysis is intended to protect the independence of the legal profession to define its own standards of conduct, not to deny the practical authority of rules of professional conduct for lawyers. ${ }^{108}$

Other Justices devalue the rules of professional conduct through benign neglect. In Maples $v$. Thomas, ${ }^{109}$ for example, two pro bono lawyers at Sullivan \& Cromwell simply stopped working on their client's state post-conviction review case, leading to a procedural default on the ineffective assistance of counsel claim he subsequently brought in a federal habeas corpus petition. ${ }^{110}$ Justice Ruth Bader Ginsburg noted that by not seeking the permission of the trial court to withdraw as counsel of record, the lawyers violated an Alabama rule of criminal procedure. ${ }^{111}$ Their conduct also violated the state disciplinary rules, which allow withdrawal of an attorney only if the withdrawal "can be accomplished without material adverse effect on the interests of the client" or if the attorney otherwise has good cause, and if the attorney obtains the court's permission. ${ }^{12}$ This is not merely a technical quibble, but rather a distinction that could make a difference in the evaluation of the attorneys' conduct. The lawyers were first required to satisfy themselves that one of seven alternative grounds for permissive withdrawal existed. ${ }^{113}$ As it happens, there was no basis for permissive withdrawal - the attorneys

107. Id: at 688-89 (citations omitted).

108. See id. at 688 ("These basic duties neither exhaustively define the obligations of counsel nor form a checklist for judicial evaluation of attorney performance.").

109. 132 S. Ct. 912 (2012).

110. Id. at $916-18$.

111. Id. at 919 .

112. See Ala. Rules of Prof'L Conduct r. 1.16 (2015) ("When a lawyer has been appointed to represent a client, withdrawal ordinarily requires approval of the appointing authority.").

113. See Ala. Rules r. 1.16(b). 
simply disregarded their obligation under the disciplinary rule. It may be that this violation did not rise to the level of constitutionally ineffective representation under the first prong of Strickland, ${ }^{114}$ but an obvious point sometimes gets overlooked: the petitioner would not have defaulted on his federal habeas petition if his attorneys at Sullivan \& Cromwell had complied with their obligation under the state rules of professional conduct.

In other cases, the Court has stressed that it relies on defense lawyers to comply with their obligations under the disciplinary rules. For example, with regard to conflicts of interest,

Defense counsel have an ethical obligation to avoid conflicting representations and to advise the court promptly when a conflict of interest arises during the course of trial. Absent special circumstances, therefore, trial courts may assume either that multiple representation entails no conflict or that the lawyer and his clients knowingly accept such risk of conflict as may exist. ${ }^{115}$

As the Court rightly noted, lawyers are in a better position to detect and handle conflicts of interest, either by obtaining the informed consent of their clients or by informing the court and seeking release from the representation. ${ }^{116}$ If courts are going to rely on lawyers' compliance with the rules, for understandable reasons such as minimizing information costs, then they should be careful not to send mixed messages about their importance.

Regardless of whether the Court's treatment of the state rules of professional conduct reflects neglect or outright hostility, it is worrisome that criminal defense lawyers may hear the message that the rules are lower-status law and can be ignored whenever compliance is inconvenient. One may certainly criticize the content of some rules for being self-serving or insufficiently rigorous. Critics of the ABA have long contended that the rules do more to protect the legal profession's

114. See Strickland v. Washington, 466 U.S. 668,687 (1984) ("First, the defendant must show that counsel's performance was deficient. This requires showing that counsel made errors so serious that counsel was not functioning as the 'counsel' guaranteed the defendant by the Sixth Amendment.").

115. Cuyler v. Sullivan, 446 U.S. 335, 346-47 (1980) (footnote omitted).

116. Id at 34647 ("An 'attorney representing two defendants in a criminal matter is in the best position professionally and ethically to determine when a conflict of interest exists or will probably develop in the course of a trial."' (internal quotation marks omitted) (quoting Holloway v. Arkansas, 435 U.S. 475, 485 (1978))). 
monopoly than to safeguard the public interest, ${ }^{117}$ and that other institutions, such as legislatures and administrative agencies, may be better situated to address certain types of professional misconduct than the profession itself. ${ }^{118}$ For the most part, however, the rules represent a coherent, normatively attractive vision of ethical lawyering. The rules emphasize the highly fiduciary nature of the lawyer-client relationship, state strict duties of loyalty, and require a reasonable degree of competence, diligence, and communication with clients. ${ }^{119}$ Certainly if the legal profession values its independence from intrusive oversight by courts, legislatures, and regulatory agencies, lawyers have a reason to follow the rules that they, as an organized profession, have adopted as a quid pro quo for a monopoly over the provision of legal services. It is understandable that courts do not want to create rigid, inflexible norms of professional conduct under the guise of interpreting the Sixth Amendment's right to effective assistance of counsel. But the duties stated in the rules do not disappear merely because there may be no federal habeas corpus remedy as a result of their violation. As the rules themselves remind courts, the law generally does, and should, presuppose voluntary compliance. ${ }^{120}$

Voluntary compliance is even more important when the profession claims the prerogative of self-regulation. Of course, the legal profession is not really self-regulating: American lawyers are subject to various court-administered sanctions for violations of professional standards,

117. See, e.g., Richard L. Abel, Why Does the ABA Promulgate Ethical Rules?, 59 TEX. L. REv. 639, 655, 658 (1981); Deborah L. Rhode, Why the ABA Bothers: A Functional Perspective on Professional Codes, 59 Tex. L. REv. 689, 697-98, 704 (1981).

118. For example, Professor Susan Koniak understands the history of lawyers' involvement in numerous financial scandals to reveal the ABA's inability to promulgate effective rules for the protection of investors. See Susan P. Koniak, When the Hurlyburly's Done: The Bar's Struggle with the SEC, 103 COLUM. L. REv. 1236, 1238 (2003) (asserting that the ABA's battles with the U.S. Securities and Exchange Commission (SEC) have "[left] lawyers free to continue helping major corporations deceive the investing public"). The problem Professor Koniak considered involves an assertion by the profession of a norm - a near-absolute duty of confidentiality-that conflicts with a more pro-disclosure norm favored by the SEC, Congress (in the Sarbanes-Oxley Act), and many state courts applying the common law of fraud. See Susan P. Koniak, The Law Between the Bar and the State, 70 N.C. L. REv. 1389, 1427, 1462 (1992). The cases on ineffective assistance of counsel, by contrast, generally do not involve a conflict between the norms supported by the legal profession and those preferred by other institutions. Instead, they involve the frequent failure of both institutions to take these norms seriously.

119. See, e.g., MOdEL RULES OF PROF'L CONDUCT rr. 1.1 (competence), 1.3 (diligence), 1.4 cmt. 1 (communication), $1.7 \mathrm{cmt} .1$ (loyalty) (AM. BAR Ass'N 2015).

120. See MOdEl RUles OF PROF'L CONDUCT pmbl. I 16 ("Compliance with the Rules, as with all law in an open society, depends primarily upon understanding and voluntary compliance, secondarily upon reinforcement by peer and public opinion and finally, when necessary, upon enforcement through disciplinary proceedings."). 
including contempt of court, money damages for negligence, disqualification from representation, and disgorgement of earned fees. ${ }^{121}$ Similarly, it is a misstatement - common enough, but inaccurate nonetheless - to assert that the prevailing customs and norms of the legal profession set the standard of effective representation under the Sixth Amendment. ${ }^{122}$ Uncritical deference to prevailing practices may have the effect of ratifying incompetent representation. ${ }^{123}$ Yet Justice O'Connor was right to be concerned about the independence of the legal profession from excessive regulation by the judiciary. ${ }^{124}$ The truth of the matter is that the judiciary and the legal profession gradually establish standards of effective representation in a back-and-forth process. As Justice John Paul Stevens wrote in Padilla v. Kentucky, ${ }^{125}$ the constitutional standard depends upon "the practice and expectation of the legal community," and the profession's own internal norms, including the rules of professional conduct, are not conclusive authority but guides to assessing competence. ${ }^{126}$ This means that when the Supreme Court establishes an important new legal principle, as it did in Martinez, ${ }^{127}$ it may take awhile for the legal profession to adjust to the change. Post-conviction lawyers need to identify the ethical obligations required in light of the holding in Martinez that ineffective assistance of counsel in state post-conviction proceedings may serve as cause to excuse what would otherwise be a procedural default. Courts must also work through the ramifications of Martinez. For example, given the responsibility of counsel to identify conflicts and bring them to the attention of the court, ${ }^{128}$ are courts warranted in continuing to rely on lawyers when there are reasons to believe that the lawyer's prior negligence is the source of the conflict? As the following Part shows, lawyers outside the criminal defense context

121. Restatement (Third) OF THE LAW Governing LaWyers $§ 6$ (AM. LAW InSt. 2000).

122. See Russell Stetler \& W. Bradley Wendel, The ABA Guidelines and the Norms of Capital Defense Representation, 41 HOFSTRA L. REV. 635, 651-53 (2013) (arguing that in ineffective assistance of counsel cases, "courts should look to what actors should do as opposed to what they sometimes do in fact").

123. Id. at 663-64.

124. See Strickland v. Washington, 466 U.S. 668, 688-89 (1984) ("Any such set of rules would interfere with the constitutionally protected independence of counsel and restrict the wide latitude counsel must have in making tactical decisions.").

125. 559 U.S. $356(2010)$.

126. Id. at $366-67$.

127. Martinez v. Ryan, 132 S. Ct. 1309, 1320 (2012); see supra text accompanying note 17.

128. See Holloway v. Arkansas, 435 U.S. 475, 485-86 (1978) (stating that "[a]n 'attorney representing two defendants in a criminal matter is in the best position professionally and ethically to determine when a conflict of interest exists or will probably develop in the course of a trial" and that "defense attorneys have the obligation, upon discovering a conflict of interests, to advise the court at once of the problem" (quoting State v. Davis, 514 P.2d 1025, 1027 (Ariz. 1973) (en banc))). 
have long struggled with the conflicts of interest that arise from credible allegations of their own incompetence within an ongoing professional relationship. ${ }^{129}$ Courts working their way through the puzzle of Martinez may find these approaches instructive as far as they go, keeping in mind that the unique features of capital defense representation may limit their utility.

\section{II. "Prior Work" CONFlicts IN Their NATURAL ENVIRONMENT}

Martinez is implicated when a lawyer representing a petitioner in federal habeas proceedings also represented that person in state postconviction proceedings. ${ }^{130}$ If the lawyer unreasonably failed to raise a meritorious claim of ineffective assistance of trial counsel in the state courts, then counsel's deficient performance can excuse the procedural default for failing to raise the claim in the right court at the right time. ${ }^{131}$ As discussed above, this failure can satisfy the "cause" requirement, which allows federal courts to adjudicate otherwise procedurally barred claims. ${ }^{132}$ Given Martinez's creation of a new path to a merits review of previously barred claims, attorneys representing petitioners in federal habeas corpus proceedings - who were also state post-conviction counsel-are now required to assess the quality of their prior representation. This assessment involves taking into account the potential benefits to the client of continuity of representation, including counsel's familiarity with the record and any hard-won relationship of trust that may have developed between the client and lawyer.

Setting aside the constitutional framework for judging the performance of counsel, as well as the complexities of procedural default under AEDPA, what would a "pure" analysis look like under the state rules of professional conduct? To help answer this question, imagine a situation roughly analogous to the Martinez dilemma, only in the context of the representation of a client in civil litigation. A common version of this scenario involves a law firm that represented a client in a transactional, advising, or regulatory matter and subsequently attempted to represent the client in litigation in which resolution of one of the issues in dispute implicates the advice given by the firm or the actions it had recommended the client take. ${ }^{133}$ Other cases involve successive

129. See infra text accompanying notes 137-39.

130. See Martinez, 132 S. Ct. at 1313.

131. See id. at 1315.

132. See id. at 1320; supra text accompanying note 17.

133. See, e.g., Red Zone LLC v. Cadwalader, Wickersham \& Taft LLP, 988 N.Y.S.2d 588 (N.Y. Sup. Ct. App. Div. 2014) (statute of limitations on malpractice claim did not begin to run while law firm that had made mistakes in transactional representation continued to negotiate and litigate over the contract); St. Simons Waterfront, LLC v. Hunter, McLean, Exley \& Dunn, P.C., 
representation in litigation. ${ }^{134}$ They all pose not only the "endgame" question of when a conflict of interest burdens a lawyer so much that it is impermissible to proceed with the representation, but also the much more subtle and complicated issue of how to proceed in the middle of a representation when either there is an allegation of incompetence or the lawyer comes to realize that she made a mistake that affects the client's legal interests. ${ }^{135}$

All of these so-called "prior-work" conflicts issues share a similar dynamic. The claim that a lawyer provided incompetent representation at least potentially creates a conflict between the interests of the client and the lawyer's personal interest in avoiding liability, discipline, or even embarrassment for having been careless. The lawyer may want to take steps to defend her pocketbook or reputation, including resisting the

746 S.E.2d 98 (Ga. 2013) (analyzing intra-firm attorney-client privilege issues arising out of a lawsuit threat issued by a current client of the law firm in real estate matters); Koen Book Distribs. v. Powell, Trachtman, Logan, Carrle, Bowman \& Lombardo, P.C., 212 F.R.D. 283 (E.D. Pa. 2002) (determining first whether conflict of interest related to prior representation existed before analyzing attorney-client privilege and work product issues); Eurocom S.A. v. Mahoney, Cohen \& Co., 522. F. Supp. 1179 (S.D.N.Y. 1979) (disqualifying law firm from representing corporation in negligence action against accountant where law firm had allegedly also been negligent and firm's negligence, if proven, would reduce the corporation's recovery under principles of comparative negligence); Veras Inv. Partners LLC v. Akin Gump Strauss Hauer \& Feld LLP, 17 Misc.3d 1103(A), 2007 WL 2792175 (N.Y. Sup. Ct., N.Y. County, Sept. 27, 2007) (outlining malpractice theory based on law firms previous advice to and subsequent representation in litigation of hedge fund managers).

134. See, e.g., Crews v. Cty. of Nassau, No. 06-CV-2610, 2007 WL 316568, at *6 (E.D.N.Y. Jan. 30, 2007) (disqualifying a lawyer who had represented a criminal defendant from representing the same client as a plaintiff in a civil rights action because the lawyer's personal interest in concealing alleged errors in the underlying criminal action posed a "significant risk of trial taint" (internal quotation marks omitted) (quoting Glueck v. Jonathan Logan, Inc., 653 F.2d 746, 748 (2d Cir. 1981))); Jamieson v. Slater, No. CV 06-1524-PHX-SMM, 2006 WL 3421788, at $* 8$ (D. Ariz. Nov. 27, 2006) (holding that a non-waivable conflict exists when an attomey is a co-defendant with a client in a malicious prosecution lawsuit); Circle Chevrolet Co. v. Giordano, Halleran \& Ciesla, 662 A.2d 509, 512 (N.J. 1995) (discussing a malpractice claim against a law firm that represented a client in litigation, made a mistake in settlement negotiations that caused prejudice to the client, and subsequently withdrew as counsel due to a conflict of interest), abrogated by Olds v. Donnelly, 696 A.2d 633 (N.J. 1997).

135. See, e.g., Colo. Bar Ass'n Ethics Comm., Formal Op. 113 (2005) ("When, by act or omission, a lawyer has made an error, and that error is likely to result in prejudice to a client's right or claim, the lawyer must promptly disclose the error to the client."); Conn. Bar Ass'n Prof'1 Ethics Comm., Informal Op. 2014-05 (2014) (holding that no conflict of interest existed where a lawyer promptly communicated a mistake to the client and took steps to ameliorate it); N.Y. State Bar Ass'n Comm. on Prof' I Ethics, Ethics Op. 734 (2000) (noting that, ordinarily, a lawyer "has an obligation to report to the client that [she] has made a significant error or omission that may give rise to a possible malpractice claim"). See generally Anthony V. Alfieri, Law Firm Malpractice Disclosure: Illustrations and Guidelines, 42 HofsTRA L. REv. 17, 46-53 (2013) (discussing the "best practice guidelines applicable to law firm malpractice disclosure disputes"). 
client's legitimate requests for information or asserting defenses that claim contributory misconduct by the client; these steps may harm the client. The lawyer's understandable desire to protect herself conflicts with the bedrock principle that a lawyer owes a fiduciary duty to the client at all times during the existence of an attorney-client relationship and must always put the client's interests first. ${ }^{136}$ The lawyer may also become so preoccupied with defending against allegations of misconduct that the client's case suffers from neglect. A further difficulty is that it may not be clear at the time whether the lawyer actually committed malpractice or provided ineffective assistance of counsel. Not all assertions of error have merit, and the lawyer may believe that her conduct was reasonable. Of course, if an allegation is serious and credible, a lawyer has a duty to inform the client of this fact, advise the client of the best way to protect her rights, and obtain the client's informed consent to the conflict if the lawyer wishes to continue representing the client. ${ }^{137}$ But a lawyer need not go through the procedure of explaining the possible conflict and obtaining informed consent every time something goes wrong that an aggrieved client might characterize as the result of negligence. A lawyer is therefore in the unenviable position of having to decide how to advise her client on the client's rights to assert claims regarding the lawyer's negligence while remaining immersed in the ongoing representation of the client in the underlying matter. The lawyer's involvement on behalf of the client makes it extremely difficult to adopt the necessary stance of detachment from which it would be possible to evaluate whether she had provided competent services to the client. The conflicts rules, which contemplate the lawyer providing independent advice to the client as part of the process of obtaining informed consent, are not well designed to handle a situation in which allegations of her own misconduct in representation potentially diminish the lawyer's capacity to provide this advice. Yet, a per se rule of disqualification would fail to reflect the reality that many allegations of malpractice or ineffective assistance of counsel are not well-founded. At the very least a lawyer should be entitled, and encouraged, to seek legal advice concerning what to do in light of an allegation of misconduct. ${ }^{138}$ Beyond that, however, the situation becomes

136. See Koen Book Distribs., 212 F.R.D. at 286 (stating that a firm's fiduciary duty to its clients is paramount to the firm's own interests).

137. MOdEL RULES OF PROF'L CONDUCT r. 1.4 (AM. BAR ASS'N 2015); see also, e.g., Garvy v. Seyfarth Shaw LLP, 966 N.E.2d 523, 528 (IIl. App. Ct. 2012) (describing how the law firm advised the client to consider obtaining separate counsel due to conflicts created by malpractice allegations).

138. See N.Y. State Bar Ass'n, Comm. on Prof'l Ethics, Ethics Op. 789 (2005), at If 13 (explaining that, although concurrent conflicts rule does not preclude consultation with in-house 
considerably more murky.

For the purposes of illustrating a civil analogue to the Martinez dilemma, consider the following hypothetical representation based on a well-known legal malpractice case. ${ }^{139}$ Lawyer represents Dealership, an automobile dealership, located on a parcel of land owned by Landlord. Dealership and Landlord have a thirty-year lease, which includes a provision that the parties renew the lease and renegotiate the amount of rent at five-year intervals. In the negotiations, Landlord proposed a complex formula for setting the amount of rent using the Consumer Price Index (CPI) as published by the U.S. Department of Labor. Lawyer conveyed this offer to his client, President of Dealership, and President asked, "What do you think?" Lawyer had taken a course in law school on accounting for lawyers but was not otherwise trained as an accountant or economist. Based on his knowledge and his general inclination to trust Landlord, Lawyer advised his client that the proposed formula was fair. On behalf of Dealership, President signed the lease renewal. The next month, President was horrified when she discovered that Landlord had increased the amount of Dealership's rent by $\$ 37,000$ per month. She sent a copy of the lease to Dealership's accountant, who quickly discovered the problem: rather than basing the amount of rent on an average of percentage increases in the CPI, Landlord based the new formula on actual increases in CPI, which had the effect of locking in temporary price increases. President informed Lawyer of the problem and asked for his advice.

Suppose under state law there is some basis for arguing that the parties did not have a meeting of the minds over the formula for calculating rent increases. Lawyer reviews the applicable cases and concludes there is about a fifty-percent chance of successfully voiding the lease renewal on the basis of a mutual mistake in fact. Lawyer also calls Landlord to explore the possibility of agreeing to modify the formula for calculating rent increases, but Landlord tells Lawyer to pound sand.

What should Lawyer do? Keeping in mind that the client has the authority to make decisions about the objectives of the representation, ${ }^{140}$ but that a lawyer should communicate all information necessary to enable the client to make informed decisions about the representation, ${ }^{141}$ what

counsel about potential malpractice claim, a firm's conclusion that it may have committed malpractice may affect its independent professional judgment and therefore be a conflict of interest).

139. Loosely based, with a few embellishments, on Circle Chevrolet Co. v. Giordano, Halleran \& Ciesla, 662 A.2d 509, 511 (N.J. 1995). For additional analysis of this case, which is well known in the legal ethics and malpractice community but perhaps not elsewhere, see Nancy J. Moore, Implications of Circle Chevrolet for Attorney Malpractice and Attorney Ethics, 28 RUTGERS L.J. 57 (1996).

140. Model Rules of Prof'L ConduCt r. 1.2(a).

141. MODEL RULES OF PROF'L CONDUCT r. 1.4(b). 
advice should he give to the client, what alternative courses of action should he recommend, and how strongly should he urge the client to take his advice? Imagine three versions of the next chapter of the story:

1. Ignore the Problem. Lawyer advises President that, in his judgment, it would be in the best interests of Dealership to file a declaratory judgment action seeking to void the lease renewal. The action would give Dealership leverage and likely induce Landlord to agree to a less onerous formula based on average CPI increases. Lawyer also recommends that Dealership's accountant be involved in any future decisions relating to the calculation of rent payments. President asks, "What other options do I have?" to which Lawyer responds, "Pay the increased rent." President reluctantly authorizes Lawyer to file the declaratory judgment action.

2. The Most Conservative Approach. Lawyer is aware of cases stating that "an attorney who realizes he or she has made a mistake must immediately notify the client of the mistake as well as the client's right to obtain new counsel and sue the attorney for negligence."142 Lawyer calls President, offers to resign as counsel, and informs President that she has a right to retain a separate attorney and file a malpractice lawsuit. "Are you crazy?" responds President, "You have represented Dealership for years, and I am not about to terminate that relationship over one little mistake. Do what you think is best for the company."

3. The Lawyerly Approach. Lawyer practices in a law firm that is large enough to have an in-house liability, lossprevention, and ethics partner. Lawyer consults with Partner, seeking advice concerning how to proceed. Partner, who does not have the same direct personal involvement with the case that Lawyer does, asks Lawyer to describe all of the facts pertaining to the negotiation of the lease renewal, including Lawyer's understanding of the formula for calculating rent. Partner also asks Lawyer to explain the reasoning underlying his judgment that Dealership should agree to the proposed rent formula. An issue arising for lawyers practicing in firms with in-house counsel is whether the attorney-client privilege protects these intra-firm communications from discovery. ${ }^{13}$ Dealership may want to

142. Circle Chevrolet, 662 A.2d at 514.

143. See, e.g., St. Simons Waterfront, LLC v. Hunter, MacLean, Exley \& Dunn, P.C., 746 S.E.2d 98, 102 (Ga. 2013); RFF Family P'ship v. Burns \& Levinson, LLP, 991 N.E.2d 1066, 1067-68 (Mass. 2013); Palmer v. Superior Court, 180 Cal. Rptr. 3d 620, 623 (Cal. Ct. App. 2014); 
know the reasons underlying Lawyer's advice about how it should proceed. However, because Lawyer has a personal interest in avoiding liability or discipline, he is entitled to obtain legal advice about how best to proceed in view of these risks. This is not just a technical issue; rather, it reveals something important about the nature of prior-work conflicts - the legal interests of the lawyer and client may diverge when there is a credible allegation of misconduct.

In this hypothetical, it is fairly clear that Lawyer made a mistake in the negotiation of the lease renewal. Nevertheless, Dealership may have good reasons to wish to continue Lawyer's representation, including the transaction costs that would result from having to locate substitute counsel and bring the new lawyer up to speed on the matter. Assume, therefore, that Dealership decided to stay with Lawyer and directed him to file the declaratory judgment action. With the consent of the parties, the judge conducted a bench trial and concluded that there was no mistake of fact. In her written decision, the judge stated that one element of the mutual mistake doctrine was the mistake by both parties or their agents

VersusLaw, Inc. v. Stoel Rives, LLP, 111 P.3d 866, 878 (Wash. Ct. App. 2005); TattleTale Alarm Sys., Inc. v. Calfee, Halter \& Griswold, LLP, No. 2:10-CV-226, 2011 WL 382627 (S.D. Ohio Feb. 3, 2011), at *1-2; Thelen Reid \& Priest LLP v. Marland, No. C 06-2071 VRW, 2007 WL 578989 (N.D. Cal. Feb. 21, 2007), at *6; Koen Book Distribs. v. Powell, Trachtman, Logan, Carrle, Bowman \& Lombardo, 212 F.R.D. 283, 284 (E.D. Pa. 2002); Bank Brussels Lambert v. Credit Lyonnais (Suisse), S.A., 220 F. Supp. 2d 283, 286 (S.D.N.Y. 2002); In re SonicBlue, Inc., No. 07-5082, 2008 WL 170562 (Bankr. N.D. Cal. Jan. 18, 2008), at *8-9. See generally Elizabeth Chambliss, The Scope of In-Firm Privilege, 80 NOTRE DAME L. REv. 1721, 1723 (2005) (addressing "the scope of the attorney-client privilege between law firm in-house counsel and other members of the firm"). Under the fiduciary exception to the attorney-client privilege, firstand highly influentially - articulated in the context of shareholder derivative actions in Garner v. Wolfinbarger, 430 F.2d 1093, 1103-04 (5th Cir. 1970), a party with a fiduciary duty cannot shield from the beneficiary communications with a legal advisor on matters related to the fiduciary's breach of duty. The prior-work conflict of the lawyer representing the client is analogous to a corporate manager's breach of fiduciary duty. An alternative route to the conclusion that intrafirm communications concerning potential malpractice are not privileged is the imputation of conflicts of interest to all lawyers associated in a firm. See MODEL RULES OF PROF'L CONDUCT r. 1.10(a). Under a strict application of the imputation rule, the firm's in-house lawyers - whose job it is to advise the firm on its own legal obligations--"have developed interests adverse to those of the firm's client." St. Simons Waterfront, 746 S.E.2d at 105. Nevertheless, many courts, including the highest courts in Massachusetts and Georgia, have concluded that the firm's interest in receiving legal advice, which is no different from that of any other client, prevails over the client's interest in obtaining information concerning the firm's breach of its duty of care. See St. Simons Waterfront, 746 S.E.2d at 107-08; RFF Family P'ship, 991 N.E.2d at 1080. As the Massachusetts Supreme Judicial Court concluded, a law firm may have its own interests, such as in the defense of litigation brought or threatened by a client, on which it is entitled to seek confidential legal advice, even while providing complete and candid disclosure of the facts relevant to the client's interests, including communications with legal advisors. See RFF Family P'ship, 991 N.E.2d at 1076. 
regarding a material fact. The judge noted that Lawyer had testified at trial (which the judge had concluded was permissible since it was a bench trial) ${ }^{144}$ that he had not made a mistake in reviewing the CPI formula. As her opinion observed, "perhaps Lawyer was motivated to minimize the possibility that he made a mistake by the understandable hesitation to admit to having been negligent in representing Dealership." The judge went on to note that there may have been grounds for reforming the lease agreement on the basis of an implied covenant of good faith and fair dealing but that Dealership had waived that claim by not asserting it in its complaint.

\section{A. Theory of Conflict}

Under the Model Rules, a conflict of interest exists if the representation of a client would be materially limited by (among other things) a personal interest of the lawyer. ${ }^{145}$ The lawyer's personal interest creates a material limitation on the representation if "there is a significant risk that a lawyer's ability to consider, recommend or carry out an appropriate course of action for the client" will be limited by the lawyer's own interests, ${ }^{146}$ including avoiding liability for malpractice or preserving his reputation. ${ }^{147} \mathrm{~A}$ court or disciplinary authority will evaluate conflicts of interest functionally. ${ }^{148}$ That is, it will ask whether the competing interest, such as duties owed to another client or the lawyer's own interests, creates a significant likelihood of interfering with the lawyer's ability to fulfill the lawyer's duties to the client. ${ }^{149}$ Those duties include providing competent representation, keeping confidences, exercising independent judgment on the client's behalf, and making decisions based solely on the lawyer's best assessment of what is best for

144. Cf. MODEl Rules of Prof'L CONDUCT r. 3.7 (lawyer as witness). The prohibition on acting as an advocate and a witness at trial is intended to prevent confusion of the trier of fact. Id. cmt. 2. The trial court may balance the danger of confusion with the prejudice to the client if the lawyer does not testify. Id. cmt. 4 .

145. Id. r.1.7(a)(2).

146. Id. r. $1.7 \mathrm{cmt}$. 8. The New York conflicts rule uses the language "differing interests" but the substance of the analysis is the same. See RoY D. SIMON, SIMON's NEW York RULES OF Professional ConduCt ANNOTATEd 306-14 (2013).

147. See ABA Comm. on Ethics \& Prof'l Responsibility, Formal Op. 94-384 (1994) (recognizing that "the representation of [a] client may be materially limited by the lawyer's own interest in avoiding discipline").

148. Several classic conflicts cases establish this functional mode of analysis. See Brennan's, Inc. v. Brennan's Rests., Inc., 590 F.2d 168, 172 (5th Cir. 1979); Westinghouse Elec. Corp. v. Kerr-McGee Corp., 580 F.2d 1311, 1319 (7th Cir. 1978); Int'l Bus. Machs. Corp. v. Levin, 579 F.2d 271, 280 (3d Cir. 1978); Cinema 5, Ltd. v. Cinerama, Inc., 528 F.2d 1384, 1386-87 (2d Cir. 1976).

149. See cases cited supra note 148 . 
the client. Importantly, the conflicts rules are risk rules, not harm rules. ${ }^{150}$ A conflict exists if there is a significant risk of interference with professional values such as loyalty and independence. ${ }^{151}$ Actual harm to the client is not an element of a conflict of interest, as understood in the civil litigation or transactional context. To put it another way, there is really no difference between actual and potential conflicts for purposes of the rules of professional conduct. If there is a significant risk that the attorney's personal interests would materially limit the representation of a client, there is a conflict of interest, period. ${ }^{152}$

A significant source of confusion when considering the relationship between the Sixth Amendment and conflict-of-interest doctrine under the rules of professional conduct is the distinction between actual and potential conflicts in Cuyler $v$. Sullivan. ${ }^{153}$ Because the conflict-ofinterest provisions of the disciplinary rules are risk rules, not harm rules, there is really no such thing as a "potential" conflict under the rules. ${ }^{154}$ Either a risk of material limitation is sufficiently significant to trigger the requirements of informed consent and waiver, or there is no conflict. ${ }^{155}$

150. See Kevin McMunigal, Rethinking Attorney Conflict of Interest Doctrine, 5 Geo. J. LEGAL ETHICS 823, 839 (1992) ("Much of conflict of interest doctrine reflects a risk avoidance approach.”).

151. See Model Rules of Prof'l ConduCt r. $1.7 \mathrm{cmt} .1$.

152. Id. r. 1.7(a)(2); see HAZARD ET AL., supra note 32, § 10.4, at 10-13 ("[I]n modern thinking about conflicts of interest, it is no longer appropriate to speak of 'potential' versus 'actual' conflicts of interest. Instead, these terms, if they are used at all, must have reference to the degree of likelihood that the risk-the potentiality - will ripen into adverse effect - the actuality.").

153. 446 U.S. 335,350 (1980) (holding that "to demonstrate a violation of his Sixth Amendment rights, a defendant must establish that an actual conflict of interest adversely affected his lawyer's performance" as opposed to a "possible conflict of interest"); see People v. Holmes, 565 N.E.2d 950, 956, 958 (IIl. 1990) (attempting to impose some order on labels such as "potential conflict" and "possible conflict").

154. That statement is true regarding the ABA Model Rules and the forty-nine states that have disciplinary rules based on the Model Rules. See supra text accompanying note 78 . California, however, retains an idiosyncratic regulatory scheme, with a blend of court rules and statutes. See supra note 78. The California conflicts of interest rule refers to the distinction between actual and potential conflicts. See CAL. RULES OF Prof'L CONDUCT r. 3-310(C)(1)-(2) (2015), http://rules.calbar.ca.gov/Portals/10/documents/2015_CaliforniaRulesofProfessionalCon duct.pdf. Judicial interpretation of the rule has brought it closer to the Model Rules. California courts have held that a potential conflict cannot be purely hypothetical but must be an identifiable scenario in which it is reasonably likely that an actual conflict will arise. See Havasu Lakeshore Invs., LLC v. Fleming, 158 Cal. Rptr. 3d 311, 319 (Ct. App. 2013); Fox Searchlight Pictures, Inc. v. Paladino, 106 Cal. Rptr. 2d 906, 913 (Ct. App. 2001). Thus, in Model Rules terms, what the California rules refer to as a potential conflict is one in which duties owed to another client materially limit the lawyer's representation of a client. $C f$. MODEL RULES OF PROF'L CONDUCT $\mathrm{r}$. 1.7(a)(2).

155. See discussion infra Sections II.B, II.C; see also Wheat v. United States, 486 U.S. 153, 162 (1988) (holding that a district court may refuse to accept waivers of conflict because it has an 
For Sixth Amendment purposes, however, federal courts do use the language of actual and potential conflicts. ${ }^{156}$ In Cuyler, two private lawyers jointly represented John Sullivan, one of three codefendants in a murder case. ${ }^{157}$ Sullivan did not raise an objection to the concurrent representation. ${ }^{158}$ After his conviction, Sullivan filed an ineffective assistance of counsel claim based on a conflict of interest arising from the concurrent representation. ${ }^{159}$ Because his lawyers did not object, Sullivan was required to show that "potential conflicts impermissibly imperil[ed] his right to a fair trial" "160 - that they were in a sense actual conflicts. As the Court put it, "a defendant who raised no objection at trial must demonstrate that an actual conflict of interest adversely affected his lawyer's performance."161 One must be careful here, however, because the definition of "actual conflict" has a great deal in common with the way the state rules of professional conduct understand the conflicts provisions as risk rules. Most importantly, an actual conflict does not equate with Strickland prejudice-a showing that there is a reasonable likelihood that but for the conflict, the result of the trial would have been different. ${ }^{162}$ Rather, once an attorney has an actual conflict of interest, the court presumes prejudice. ${ }^{163}$ What, then, is an actual conflict of interest if not something that likely had an effect on the outcome of the trial? Considering the cases cited by the Court in Cuyler and the interpretation of Cuyler by subsequent cases, it is apparent that the standard of an "actual conflict of interest [that] adversely affected" the performance of counsel $^{164}$ is not a two-element test. In other words, an actual conflict is one that adversely affects counsel's performance, as opposed to a merely theoretical possibility of an interference with the loyalties of the

obligation to monitor proceedings for conflicts and must do so from "the murkier pretrial context when relationships between parties are seen through a glass, darkly").

156. See, e.g., Cuyler, 446 U.S. at 350.

157. Id. at 337 .

158. Id at 337-38. The lack of objection distinguishes the case from Holloway v. Arkansas, 435 U.S. 475, 477 (1978), where the trial court refused to investigate the possibility of a conflict of interest despite the lawyer's timely objection to being appointed to represent three codefendants concurrently.

159. Cuyler, 446 U.S. at 338.

160. Id. at 348 .

161. Id.

162. See Strickland v. Washington, 466 U.S. 668, 694 (1984). The Court decided Cuyler before Strickland, so obviously it could not have explicitly made reference to the second, prejudice prong of Strickland, but subsequent cases have made the relationship between these two standards clear. See, e.g., Mickens v. Taylor, 535 U.S. 162, 166, 168, 171 (2002).

163. Cuyler, 446 U.S. at $349-50$.

164. Id. at 350 . 
lawyer. ${ }^{165}$ This is somewhere between the Model Rule 1.7(a)(2) standard of a significant risk of a material limitation on the representation, on the one hand, and a showing of actual harm or Strickland prejudice on the other.

To emphasize, concluding that a conflict of interest does not invoke the presumption of prejudice under Cuyler does not take the conduct out from the state disciplinary rules. For example, a lawyer who obtains media rights to a portrayal based on information relating to the representation of a client violates a clear and unambiguous provision in the state disciplinary rules. ${ }^{166}$ The U.S. Court of Appeals for the Fifth Circuit has held, however, that the client must still show Strickland prejudice to establish a claim of ineffective assistance of counsel based on this conflict of interest. ${ }^{167}$ Whatever one thinks of the court's reasoning in Beets, there is no suggestion that the lawyer's conduct was anything other than an act of self-interest that breached the lawyer's fundamental fiduciary obligation to his client. The court lists other types of conflict for which the second prong of Strickland must be satisfied and, like the media-rights case, all are clear violations of the disciplinary rules - accepting a case when the lawyer is too busy to handle it competently; accepting payment from someone other than the client without obtaining the client's informed consent; and continuing to represent a client when it is likely that the attorney will be called as a witness. ${ }^{168}$ There is a conflict in all of these cases-the lawyer acted improperly-notwithstanding the inapplicability of the Cuyler presumption. Interestingly, the court mentions a fourth situation: "An attorney has neglected to file a competency motion. To cover up the mistake, it is alleged, he tardily files an inadequate motion." 169 This is exactly the problem considered here and, regardless of whether it falls within the Cuyler presumption, it is clearly a conflict of interest under the rules.

In the hypothetical discussed above, in Model Rules terms, what did Lawyer do wrong that constituted a conflict of interest? Obviously he erred by misunderstanding rent calculation under the new formula proposed by Landlord. But that is a simple failure of competence, not a conflict of interest. A conflict requires a substantial likelihood of interference with the performance of a duty that counsel owes to the

165. See Mickens, 535 U.S. at 171 (““[A]n actual conflict of interest' mean[s] precisely a conflict that affected counsel's performance-as opposed to a mere theoretical division of loyalties.").

166. See Model Rules of Prof'l Conduct r. 1.8(d) (AM. BAR ASs'N 2015).

167. Beets v. Scott, 65 F.3d 1258, 1266-69 (5th Cir. 1995).

168. Id. at 1271; MODEL RULES OF PROF'L CONDUCT rr. 1.1, 1.8(f), 3.7.

169. Beets, 65 F.3d at 1271 . 
client. ${ }^{170}$ The conflict manifests itself later, when Lawyer is advising his client, Dealership, acting through its duly authorized agent, President, about what to do next. Lawyer's own interest may be to cover up or minimize the mistake, and this interest may cause him to be excessively optimistic when reading the cases on the mistake-of-fact defense. This personal interest materially limits Lawyer's representation of Dealership because it creates a significant risk that Lawyer will not be able to advise Dealership competently and provide the independent advice owed to the client. ${ }^{171}$ The essence of the conflict is the failure of Lawyer's impartiality caused by Lawyer's own interest in avoiding liability or discipline.

\section{B. Waivability}

Under the Model Rules, most concurrent conflicts of interest are consentable or waivable (used interchangeably) with full disclosure. Certain conflicts are not waivable, however. ${ }^{172}$ The three categories of non-waivable conflicts are (i) representations prohibited by law, ${ }^{173}$ (ii) assertion of a claim against another client represented by the lawyer in the same litigation, ${ }^{174}$ and (iii) conflicts so severe that the lawyer could not reasonably believe it possible to provide competent and diligent representation to both clients. ${ }^{175}$ Categories (i) and (ii) state per se rules of non-waivability but are relatively narrow in scope. In criminal defense representation and in the context of prior-work conflicts, non-waivable conflicts will generally fall within the third category. A non-consentable conflict would arise from a mistake so serious that no reasonable lawyer could believe it is possible to provide effective representation to the client while worrying about her own potential liability.

Many conflicts may be waivable in theory, but for practical reasons it

170. See Model RULES OF Prof'L CONDUCT r. $1.7 \mathrm{cmt} .8$ (explaining when a conflict will rise to a violation of the rule).

171. See id. r. 1.7(a)(2) (addressing material-limitation conflicts); id. r. 1.1 (addressing competence); id. r. 2.1 (addressing independence).

172. Id. $\mathrm{r}$. 1.7(b). The non-waivability provision of the concurrent conflicts rule is drafted negatively, so it actually states conditions for a conflict to be waivable. That is, a conflict is waivable if it does not fall into one of the three specified categories. See id.

173. Id. r. 1.7(b)(2). This is a relatively limited category of non-waivable conflicts, the most common instance of which is when a statute or regulation applicable to a former government official prohibits a lawyer from representing a client in private practice. See id. r. $1.7 \mathrm{cmt}$. 16; RESTATEMENT (THIRD) OF THE LAW GOVERNING LAWYERS $\$ 122 \mathrm{cmt}$ g(i) (AM. LAW INST. 2000).

174. MODEL RULES OF PROF'L CONDUCT r. 1.7(b)(3). Note that this standard differs from one of the tests for defining a conflict of interest. A conflict may exist if the interests of one client are directly adverse to the interests of another client of the lawyer or law firm. Id. r. 1.7(a)(1). The conflict is only non-waivable, however, if the lawyer or firm attempts to represent both sides of the litigation simultaneously. Id. r. 1.7(b)(3).

175. Id. r. 1.7(b)(1); RESTATEMENT (THIRD) OF THE LAW GOVERNING LAWYERS $§ 122 \mathrm{cmt}$. g(iii). 
may be impossible to obtain informed consent. A frequent scenario in private practice, though unlikely to arise in criminal defense representation, occurs when the lawyer has confidential information regarding one client that the lawyer would ordinarily have to disclose to another client as part of the process of obtaining both clients' informed consent to a conflict of interest. ${ }^{176} \mathrm{~A}$ problem more likely to exist in the Martinez dilemma is that the lawyer's own involvement in the ineffective representation makes it difficult for the lawyer to provide the kind of candid, impartial disclosure to which the client is entitled. This is technically a failure of informed consent, not an evaluation of the conflict as non-waivable. A further problem that may arise in the case of multiple representation in a criminal defense matter, but not civil litigation, is that the district court has the authority to decline to accept waivers of conflicts of interest. ${ }^{177}$ A lawyer may believe a conflict is waivable and obtain the client's informed consent, yet the court may nevertheless disqualify the lawyer under Rule 44(c) of the Federal Rules of Criminal Procedure.

\section{Informed Consent and Its Limitations}

If a conflict is consentable-and most are-informed consent requires that the lawyer provide full disclosure of "the relevant circumstances and of the material and reasonably foreseeable ways that the conflict could have adverse effects on the interests of that client." ${ }^{178}$ The purpose of the

176. See, e.g., Ass'n of the Bar of the City of New York, Formal Op. 2005-02 (2005).

177. Wheat v. United States, 486 U.S. 153, 160-63 (1988). If the district court is too deferential to prosecutors who are insisting on the disqualification of defense counsel for some highly speculative theory of a conflict, the result may be to deprive defendants of the counsel of their choice - and sometimes highly effective defense counsel- with no corresponding gain in the protection afforded by the conflicts rules to either the interests of defendants or the integrity of the adversarial process. See Bruce A. Green, "Through a Glass, Darkly": How the Court Sees Motions to Disqualify Criminal Defense Lawyers, 89 CoLuM. L. REv. 1201, 1250 (1989) ("The defendant has an interest in receiving the effective assistance of counsel, in receiving the assistance of his attorney of choice, and in deciding for himself whether to undertake the risks attendant to counsel's potential conflict. These interests are obviously undermined by the defense counsel's disqualification, which may deprive the defendant of the possible strategic advantage of being represented by a particular attorney and may derogate his interest in deciding for himself whether to continue with an attorney who may have a conflict or to seek different representation.").

178. MODEL RULES OF PROF'L CONDUCT r. $1.7 \mathrm{cmt}$. 18. "Informed consent" is a defined term in the Model Rules. See id. r. 1.0(e) (defining "informed consent" as the "agreement by a person to a proposed course of conduct after the lawyer has communicated adequate information and explanation about the material risks of and reasonably available alternatives to the proposed course of conduct"). The 1983 version of the Model Rules used the term "consent after consultation." See ABA Comm. on Ethics \& Prof's Responsibility, Formal Op. 05-436 (2005) (noting that in 2002 the ABA Commission of Evaluation of the Rules of Professional Conduct replaced the term "consent after consultation" with the term "informed consent"). Although the term "informed consent" is preferable, due to its association-drawn intentionally by the drafters 
informed-consent standard is to permit the client to make an autonomous decision to proceed with the representation despite the existence of a conflict. The client may decide, for example, that the cost and inconvenience of switching lawyers is not worth it, given what the client perceives as only a slight risk that a conflict of interest will impair the lawyer's ability to provide competent and diligent representation. The overarching idea of informed consent is that many decisions regarding the representation are for the client to make, but the lawyer must give the client sufficient information to participate intelligently in the decisionmaking process. ${ }^{179}$ The lawyer has a fiduciary duty to act in her client's best interests, as the client defines them, after consultation. ${ }^{180}$ The agency or fiduciary model of allocation of decision-making authority, recognized by the common law of agency and the Model Rules, ${ }^{181}$ presupposes both the client's ability to participate in the decision-making process and the attorney's ability (and willingness) to communicate all relevant information. Because clients frequently lack the expertise necessary to make decisions about their legal rights and liabilities, they are necessarily dependent upon their lawyer. The attorney and client thus have coordinating roles in decision-making. The client has the final authority with respect to the objectives of the representation, but the lawyer owes the client fully informed, candid, and impartial advice by a lawyer acting solely in the client's best interests.

The informed-consent standard is similar to the "knowing and intelligent waiver" test used in many areas of criminal procedure. For example, the Supreme Court in Moran v. Burbine, ${ }^{182}$ evaluating a waiver of a suspect's Miranda rights, asked whether the suspect waived those rights with "full awareness of both the nature of the right being abandoned and the consequences of the decision to abandon it." 183 The informed-consent standard in civil conflicts-of-interest law "requires that each affected client be aware of the material respects in which the

of the Ethics 2000 version of the Model Rules - with the doctrine of informed consent in medical malpractice law, the older term "consent after consultation" does have the virtue of reminding lawyers that they first have an obligation to consult with their clients before seeking the client's waiver. See HAZARD ET AL., supra note $32, \S 10.8$, at 10-23 (emphasizing the initial step of full disclosure to the client of all aspects of the conflict). See generally Susan R. Martyn, Informed Consent in the Practice of Law, 48 GEO. WASH. L. REv. 307 (1980) (tracing the development of informed consent in medical malpractice law and the law governing lawyers).

179. HAZARD ET AL., supra note $32, \S 7.4$, at 7-7 ("If the client is to make turning-point decisions about his legal affairs, he must be armed with sufficient information for intelligent decisionmaking.").

180. See Model Rules of Prof'L Conduct r. 1.2(a).

181. See id.

182. Moran v. Burbine, 475 U.S. 412 (1986).

183. Id. at 421 . 
representation could have adverse effects on the interests of that client." ${ }^{184}$ Conflicts involving credible allegations of attorney misconduct present a difficult variation on the problem of obtaining informed consent. In the prior-work conflicts hypothetical this Article considers, the issue is not merely that the adverse effect of the lawyer's mistake on the client's interests might be expensive and time-consuming to unwind, and might have further consequences down the line. The further adverse effect is that the attorney's reluctance to "fess up" to a mistake compromises the lawyer's own ability to give that advice. The lawyer's inability to provide fully candid, impartial advice impairs the client's capacity to make fully informed decisions concerning the representation. ${ }^{185}$

Complicating the process of providing full disclosure is the possibility that the lawyer's desire not to admit his mistakes may operate at an unconscious level. In an important article on lawyer liability for aiding and abetting client fraud, Professor Don Langevoort reviews the empirical literature on social cognition and concludes that certain cognitive effects present an obstacle to lawyers perceiving the warning signs of fraud. ${ }^{186}$ Importantly, many of these processes occur at.the unconscious or "preconscious" level, so the actor sincerely believes she is acting rationally. ${ }^{187}$ For example, once someone is committed to a position, "the subsequent discovery of information that indicates harmful consequences flowing from that commitment directly threatens their selfconcept as good, worthwhile individuals," with the result that the person suppresses or ignores certain information that should function as a "red flag" warning of danger. ${ }^{188}$ The phenomenon of escalating commitment - gamblers doubling down on a losing hand or bankers throwing good money after bad - can be explained in this way. ${ }^{189}$ In the case of prior-work conflicts caused by the lawyer's malpractice, it is likely that the lawyer ignored at least some evidence of having made a mistake and will therefore not be in a position to provide the kind of candid, impartial advice that the client deserves and is entitled to under the doctrine of informed consent. ${ }^{190}$

184. RESTATEMENT (THIRD) OF THE LAW GOVERNING LAWYERS $\S 122 \mathrm{cmt} . \mathrm{c}(\mathrm{i})$ (AM. LAW INST. 2000).

185. See Martyn, supra note 178 , at 330 (recognizing the material impairment to a client's decision-making when the lawyer has not fully informed the client).

186. See Donald C. Langevoort, Where Were the Lawyers? A Behavioral Inquiry into Lawyers' Responsibility for Clients' Fraud, 46 VAND. L. REV. 75, 95-96 (1993).

187. Id. at 97.

188. Id. at $102-03$.

189. Id. at 103.

190. Pertinent to the issues considered here, Professor Tigran Eldred recently published an application of the research on this kind of motivated reasoning to the ethical obligations of 
It is important to stress that this occurs unconsciously, so that the actor is unaware of her blind spot with respect to this evidence. ${ }^{191}$ A lawyer may believe, in absolute, subjective good faith, that she has provided effective representation to the client even though an impartial observer not affected by the same perceptual and cognitive limitations could discern the malpractice. An attorney may believe she is fully disclosing to the client all material effects on the client's interests, but she will in fact not be fully informing the client because of unconscious processes that lead to the construal of some of the attorney's actions as not mistakes at all. It is a natural human reaction to attempt to minimize the responsibility for one's own failings:
Commonly, lawyers against whom [allegations of ineffective assistance of counsel] are raised react with disappointment, outrage, and anger. When these feelings subside, the next usual response is to develop a strategy to defend the allegations. Unfortunately, from that point on, many attorneys facing a claim of ineffective assistance tend to distance themselves from the former clients and even to create an adversarial relationship between themselves and their former clients. ${ }^{192}$

The result of this process of an attorney coming to grips with her mistakes, however, may be that the informed-consent standard is not doing the work it is designed to do-allowing the client to make autonomous decisions about whether to proceed with a representation despite the existence of a conflict of interest-because the lawyer's inability to perceive her mistakes clearly may interfere with the attorney's role as the advisor to the client. To make this discussion less abstract, return to the hypothetical of the prior-work conflict of interest but vary the facts slightly: Imagine that President was surprised to find that the rental payment had increased significantly and asked Lawyer to explain why this had occurred. Lawyer is now looking back at his conduct in the course of renegotiating the lease, considering at least two possibilities: (1) "I screwed up" and (2) "Landlord screwed me."

predecessor counsel in capital cases. See generally Tigran W. Eldred, Motivation Matters: Guideline 10.13 and Other Mechanisms for Preventing Lawyers from Surrendering to SelfInterest in Responding to Allegations of Ineffective Assistance in Death Penalty Cases, 42 HOFSTRA L. REV. 473 (2013).

191. See generally MaX H. Bazerman \& Ann E. Tenbrunsel, Blind Spots: Why We Fall TO Do WHAT's Right AND WHAT TO DO ABOUT IT (2012) (discussing ethical blind spots, the gap between what a person wants to be and what the person actually is, and ways to be aware of and remove these blind spots).

192. Eldred, supra note 190, at 486 (quoting Michael Mears, The Defense Attorney's Ethical Response to Ineffective Assistance of Counsel Claims, G. B.J., Oct. 1999, at 40, 42) (alteration in original). 
The unconscious psychological process of motivated reasoning makes it likely that Lawyer will tend to attribute the explanation for the increased rent to some trickiness or deception by Landlord. In fact, from an objective point of view, Lawyer's conduct fell below the applicable standard of care- "the competence and diligence normally exercised by lawyers in similar circumstances." 193 But clients do not receive information and advice from an objective point of view. Their legal advisors, in large part, provide their understanding of the available options and the risks and benefits associated with each of them. There is thus a significant likelihood that Lawyer may not inform President that the client, Dealership, has the option of filing a declaratory judgment action to void the new lease on the ground of a mutual mistake of fact. The informed-consent standard works only if the client has full information, but the lawyer's dual role as provider of information and cause of the problem limits the provision of full information. The lawyer is responsible for ensuring that the client has adequate information, but the lawyer's discomfiture at an accusation of making a mistake impairs her ability to carry out this responsibility.

Would it help to require lawyers to recommend that their clients consult with independent counsel when there is a credible allegation of misconduct? The Model Rules suggest that "[i]n some circumstances it may be appropriate for a lawyer to advise a client ... to seek the advice of other counsel," 194 but again the operation of this norm depends on a prior determination by the lawyer either that the lawyer made a mistake or that an allegation of wrongdoing is credible. Clients may accuse lawyers of malpractice absent valid grounds, and it would be unduly cumbersome and expensive to require that lawyers recommend that their clients consult with independent counsel whenever there is any allegation of carelessness. It appears to be impossible to avoid the critical threshold judgment of the existence of a conflict of interest being made by the lawyer whose conduct has been called into question.

\section{Clients with Diminished Decision-Making Capacity}

All of this analysis of the allocation of decision-making authority in the attorney-client relationship assumes that the client has the capacity to understand and act upon information pertaining to his rights and options going forward. The theoretical ground for the informed-consent doctrine is the value of autonomy and the right of competent adult clients to make decisions pertaining to their own well-being. ${ }^{195}$ Clients with ordinary decision-making capacity should be allowed to choose among a variety

193. Restatement (ThiRd) OF THE LAw Governing LAWYERS $§ 52(1)$ (AM. LAw Inst. 2000).

194. MOdel Rules of Prof'L ConduCt r. $1.0 \mathrm{cmt} 6$ (AM. BAR Ass'N 2015).

195. See Martyn, supra note 178 , at 312. 
of options for the representation, provided they are fully informed about the risks and benefits of their choices. But there are many clients whose "capacity to make adequately considered decisions in connection with the representation is diminished ... because of minority, physical illness, mental disability, or other cause. $" 196$

In these cases, the Model Rules rather unhelpfully instruct lawyers to maintain as normal an attorney-client relationship as possible. ${ }^{197}$ To the extent this means only treating the client with respect, listening carefully, and trying to ascertain the client's views about his interests, this is perfectly sensible advice. But when it comes to making critical decisions about the representation, lawyers cannot rely on clients with diminished capacity to provide effective informed consent. They may have the option to seek the appointment of a guardian to make decisions on behalf of the client, ${ }^{198}$ but if no representative is available to make these decisions, the lawyer may have no choice but to muddle through, acting on the basis of the lawyer's reasonable view of the client's interests if the client were able to make adequately considered decisions. ${ }^{199}$ A lawyer's personal interest in covering up the mistake therefore affects the lawyer who makes a mistake in the course of representing a client with diminished capacity at two levels - first, in recognizing the mistake and the conflict it may have caused and second, in reaching a decision about what would be in the client's best interests.

The diminished-capacity problem arises even for lawyers who are completely conflict-free. Take the case of a lawyer representing a client on death row who has instructed the lawyer that he has decided to "accept responsibility" for his crimes and that the lawyer should waive all appeals and should in all other respects simply acquiesce in the imposition of the death sentence. ${ }^{200}$ As long as the defendant has a rational and factual understanding of the consequences of his decision, ${ }^{201}$ which is an extremely lenient standard for competency, he theoretically has the right to waive his appeals. ${ }^{202}$ In principle, this means his lawyer must "abide by [the] client's decisions concerning the objectives of representation."203

196. RESTATEMENT (THIRD) OF THE LAW GOVERNING LAWYERS $§ 24(1)$.

197. MODEL RULES OF PROF'L CONDUCT r. 1.14(a) ("[T]he lawyer shall, as far as reasonably possible, maintain a normal client-lawyer relationship with the client.").

198. See id. r. 1.14(b).

199. RESTATEMENT (THIRD) OF THE LAW GOVERNING LAWYERS § 24(2).

200. See John H. Blume, Killing the Willing: "Volunteers," Suicide and Competency, 103 MiCH. L. REV. 939, 939-40, 982 (2005) (asking whether a death row inmate who wishes to waive his appeals should be viewed as a client accepting the justness of his punishment or as a person seeking the aid of the state in committing suicide).

201. Godinez v. Moran, 509 U.S. 389 (1993).

202. See Blume, supra note 200 , at $945,946$.

203. MODEL RULES OF PROF'L CONDUCT r. 1.2(a). 
As experienced capital defense lawyers know, however, serious mental illness is common among their clients, and even those who do not have chronic, untreated mental illness often suffer from episodic bouts of depression, which can temporarily interfere with their ability to make rational decisions. ${ }^{204}$ Many of these same clients have subsequently expressed deep gratitude to their lawyers for not acting on instructions to waive appeals. ${ }^{205}$ But the law governing lawyers does not really recognize this possibility. If anything, the law is so strongly committed to the value of client autonomy that it goes too far in discouraging lawyers from trying to talk sense into despondent clients or taking other actions in the client's long-term best interest. For example, the Restatement comments on the diminished-capacity rule warn lawyers not to infer a disability from their clients' seemingly irrational instructions: "Lawyers ... should be careful not to construe as proof of disability a client's insistence on a view of the client's welfare that a lawyer considers unwise or otherwise at variance with the lawyer's own views."206 This is sound advice in the mine run of cases, but in light of the prevalence of serious mental illness and cognitive disabilities among death row inmates, capital defense lawyers need some latitude to act on their assessment of what is best for their clients when there is reasonable doubt about the client's capacity to make an informed decision.

Many lawyers would object on the ground of paternalism to the Restatement's directive to pursue the client's interests as the client would define them "if able to make adequately considered decisions," 207 even if the lawyer were acting in the utmost good faith, without any personal bias. The lawyers who represented the Unabomber, Ted Kaczynski, and persuaded (or tricked) him into allowing them to put on mental-status evidence ${ }^{208}$ were not biased or incompetent-in fact, the dissenting judge went out of his way to call them "superb" lawyers. ${ }^{209}$ Nevertheless, they were criticized for overriding their client's express instruction that they not portray him as mentally ill. ${ }^{210}$ As Professor David Luban argues, they violated Kaczynski's right to be treated with dignity by "rid[ing] roughshod over the commitments that make the client's life meaningful and so impart dignity to it."211 Of course, they did so based on the belief that Kaczynski's life commitments would be all for naught if the state

204. See Blume, supra note 200 , at 944,968 .

205. See id. at 940.

206. RESTATEMENT (THIRD) OF THE LAW GOVERNING LAWYERS $\$ 24$, cmt. c.

207. Id. $\$ 24(2)$ (emphasis added).

208. See United States v. Kaczynski, 239 F.3d 1108, 1110 (9th Cir. 2001).

209. See id. at 1121 (Reinhardt, J., dissenting).

210. Id.

211. David Luban, Legal Ethics and Human Dignity 76-77 (2007). 
executed him. ${ }^{212}$ There are good moral arguments for both courses of action in this case - either respecting Kaczynski's commitments even at the expense of allowing him to participate in judicially sanctioned suicide or overriding his commitments in an effort to save his life. Where the lawyer is laboring under a conflict due to a prior instance of incompetent representation, however, there is even less reason to grant decisionmaking authority to the lawyer at the expense of the client. The actions of Kaczynzski's lawyers were admirable because their objective, preventing his execution, is one that a rational person could share. (Whether the judicial system should permit a seriously mentally ill person to represent himself and thereby consent to "an execution following a trial that lacked the fundamental elements of due process, and was farcical at worst," 213 is a separate matter.) But there is nothing admirable about a lawyer who overrides his client's directives out of a desire to hide his own malpractice. This observation only sharpens the issue of the representation of capital defendants with diminished capacity. To the extent a lawyer has the authority to "pursue the lawyer's reasonable view of the client's objectives or interests," 214 the capacity of the informedconsent doctrine to protect client interests is weakened. Throw in the problem of conflicts of interest and the problem of alienation of clients from their constitutional entitlement to effective assistance of counsel becomes even more acute.

\section{Why CRIMINAl DefEnSe, AND PaRTicularly CAPITAL DEFENSE, IS DIFFERENT}

The reflexive response to the Martinez problem is obvious: state postconviction counsel should not represent capital clients in subsequent federal habeas corpus proceedings because of the possibility of conflicts of interest. Judges should appoint new counsel to represent the client in federal court. If the failure to raise a claim adequately, or at all, in the state courts can transform a claim that is procedurally defaulted into one that federal courts can entertain on the merits, then someone other than the lawyer who represented the client in state courts must review the record and conduct an investigation to see if there are any such claims. Lawyers are generally not allowed to assess-much less litigate - the quality of their own representation. Thus, because of the potential conflict of interest state post-conviction counsel inevitably has, new counsel is needed in federal habeas corpus proceedings to determine whether there

212. See id. at 77 (arguing that Kaczynski had a different theory of his case than his lawyers, but Kaczynski eventually and reluctantly took his lawyers' advice).

213. Kaczynski, 239 F.3d at 1128 (Reinhardt, J., dissenting).

214. Restatement (Third) OF THE LAW GOVERNING LAWYERS $§ 24(2)$ (AM. LAW InST. 1998). 
are additional claims of ineffective assistance of trial counsel that should have been raised in the prior state collateral proceedings. ${ }^{215}$ Some courts, in fact, have taken this reflexive position. ${ }^{216}$

But, is it always in a death row inmate's best interests for state postconviction counsel to be relieved and for new counsel to be appointed? Clearly not; in many-if not most-jurisdictions, the number of competent and experienced capital post-conviction counsel is quite small. The relieved state collateral appeals attorney may be quite experienced and very skilled, and the new lawyers that will be appointed may not be nearly as competent. Given that it is often unknown whether anything was overlooked in state post-conviction proceedings, and if so, whether anything not raised is potentially meritorious, a disruption in representation is definitely not always in the client's best interests. In other cases, the attorney-client relationship that has developed may be so strong that a disruption in representation could have significant adverse effects on the client's mental state or willingness to proceed with the appeals. $^{217}$ Thus, it is not difficult to envision cases in which sticking with long-time counsel offers the inmate the best chance to prevail and thus to live. The difficulty lies in determining which category a particular case falls in. The problem is exacerbated by the fact that an inmate generally makes this type of decision with the advice of counsel, but in the cases this Article describes, counsel is the very lawyer whose past errors may entitle the inmate to proceed with what would otherwise be procedurally defaulted claims.

Thus, the ethical conundrum is how to assess whether state postconviction counsel can or should continue to represent the client in federal habeas corpus proceedings. In the abstract, it would be

215. In theory, the same analysis would apply in non-capital cases as well. But, this Article limits its discussion to capital cases for several reasons. First, in non-capital cases, inmates seeking state collateral relief are often unrepresented; thus, counsel will not have the opportunity to provide substandard representation. And because non-death-sentenced inmates are not entitled to court-appointed counsel in federal habeas corpus proceedings, most are unrepresented in federal court as well. Thus, in the small percentage of cases where this issue arises, if counsel were to withdraw following state post-conviction proceedings, the client would be left without any representation. Second, despite often being "honored in the breach," this Article also falls back on the simple reality that "death is different."

216. Owens v. Stirling, No. o:15;mc-00254-TLW-PJG (D.S.C. Aug. 13, 2015) (refusing to appoint state PCR counsel in habeas corpus proceedings after attorney general objected to their appointment based on a potential conflict of interest).

217. Clients who attempt to waive their appeals and submit to execution are frequently referred to as "volunteers." Blume, supra note 200 , at 940 . Approximately twelve percent of all people executed in the United States are volunteers. Id. at 1008. Most have a serious mental illness, and disruptions in relationships can trigger the decision. Id. at 962 . Thus, it is not impossible to imagine situations where a change in counsel could render a death row inmate so distraught that he decided to "volunteer" for execution. 
theoretically possible to have independent counsel (1) review the record of the proceedings below, (2) conduct any needed investigation, (3) consult with the client about the pros and cons of having former counsel continue with the representation, and (4) allow the client to make a knowing and intelligent decision as to how to proceed. ${ }^{218}$ Again, in theory, the client would then be in a position to decide whether to request new counsel or to waive any potential conflict of interest arising from continued representation, i.e., give informed consent. ${ }^{219}$ But this ideal poses several practical problems as well, such as: who will those lawyers be, and who will compensate them? Given both the small number of attorneys competent to represent a death-sentenced inmate in federal habeas corpus proceedings and fiscal constraints in difficult economic times, systemic resistance to such a proposal is not difficult to imagine. It also raises questions of efficiency, i.e., if the court is going to pay someone to review the files, investigate the case, and become sufficiently "up to speed" to advise the client on the benefits and dangers of continued representation, then why not just appoint new counsel? Courts may also worry about the informal game-theoretic implications of Martinez, such as whether lawyers might attempt to sandbag by committing an error in state post-conviction proceedings that they could then subsequently raise as a ground for filing a federal habeas petition, all with a view toward creating delay and prolonging the life of their client.

A less cumbersome procedure would be to have independent counsel explain to the client that inadequate assistance of state post-conviction counsel may be a gateway to merits' review of defaulted claims of ineffective assistance of trial counsel and that proceeding with current counsel would constitute a waiver of any such claims. While better than nothing, this hardly seems adequate for a knowing and intelligent waiver of the potential conflict of interest. Without the type of review described above, neither the attorney providing the "advice" nor the client will have an accurate assessment of the risks of continuing with state postconviction counsel. Thus, it is difficult to see how any purported waiver could in any real sense be knowing and intelligent.

Another option would be to place the initial responsibility of determining whether new counsel is needed on state post-conviction counsel. Upon entering federal habeas corpus proceedings, state post-

218. This approach has also been used in a few cases. See, e.g., Folwer v. Joyner, 753 F.3d 446 (4th Cir. 2014); Gray v. Pearson, 526 F. App'x. 331 (4th Cir. 2013).

219. See Christeson v. Roper, 135 S. Ct. 891, 893 (2015) (depicting independent counsel advising client not to waive the prior-work conflict by filing motion for substition). Again, however, the situation in Christeson is somewhat anomalous because the petitioner's original, incompetent attorneys asked two independent lawyers for advice on the case. Id. at 892 . The independent lawyers then noticed the conflict and moved for substitution of counsel. Id. at 89293. If the original two attorneys had not asked for this advice the client may never have found out about the conflict. See id. at 892. 
conviction counsel-assuming she desires to continue representing the client - would be required to reassess the quality of her representation in state proceedings and then advise the client whether new counsel is needed. However, simply to state it as an option is to expose its patent deficiencies; state post-conviction counsel is frequently in no position to determine whether their own performance was inadequate, particularly given the psychological reality of having blind spots regarding one's own ethical shortcomings. Furthermore, given the federal statute of limitations for federal habeas petitions and rules forbidding amendments to a habeas petition after the limitations period has expired, new counsel's hands could be tied even if substantial issues were uncovered. ${ }^{220}$

Thus, the question remains: What to do? There are a few clear scenarios. In cases pending in federal court, federal habeas counsel clearly has a potential conflict of interest where:

(a) federal habeas counsel represented the petitioner in state court; and

(b) counsel for the state has alleged that one or more claims of ineffective assistance of trial counsel are procedurally defaulted because they were not raised (at all or adequately) in the state court proceedings.

In such cases, current habeas counsel must move to be relieved and request appointment of conflict-free counsel who can assert inadequate assistance of state post-conviction counsel as "cause" for the alleged default unless:

(a) counsel for the state waives the procedural defense (as this Article contends he should when there are credible grounds for believing the defense attorney has a prior-work conflict and independent counsel is not available ${ }^{221}$ );

(b) the court concludes that the claim is not in fact barred because counsel fairly presented the claim to the state courts or for some other reason (e.g., the alleged default is not adequate or independent of federal law); or

(c) the court determines the claim is not "substantial" because it patently lacks merit.

Similarly, there are instances where state post-conviction counsel

220. See infra note 230.

221. Procedural default is an affirmative defense and, as such, can be waived. Trest $v$. Cain, 522 U.S. 87, 89 (1997) ("'P]rocedural default is normally a 'defense' that the State is 'obligated to raise' and 'preserv[e]' if it is not to 'lose the right to assert the defense thereafter." (alteration in original)). 
intends to continue as federal habeas counsel and the federal courts have appointed that counsel under the Criminal Justice Act pursuant to the Supreme Court's decision in McFarland $v$. Scott, ${ }^{222}$ and in the course of preparing the petition for writ of habeas corpus discovers one or more potential claims of ineffective assistance of trial counsel that were not raised in the state collateral proceedings (or not raised adequately). In these instances, counsel has an obligation to inform the court and the client and to ask the court to appoint counsel who is not laboring under a potential conflict of interest for, at a minimum, the purpose of advising the clients of the pros and cons of proceeding with current counsel. If the court denies the request, counsel is obligated to file a motion to be relieved based upon the potential conflict of interest. Only if the court denies the motion should counsel continue with the federal representation.

These scenarios (and Martinez itself) raise a more fundamental issue: if state post-conviction counsel intends to continue representing a capital client in subsequent federal habeas corpus proceedings (after explaining the Martinez equitable "exception" to the client and ascertaining that the client wants counsel to continue), does counsel have an affirmative obligation to actually investigate the quality of their prior state court representation to assess - in the parlance of Martinez - its adequacy? The answer to this is also clear. Yes, counsel does. As counterintuitive as it may seem at first blush, in the post-Martinez world, where the failure to raise ineffective assistance of trial counsel claims in state post-conviction proceedings can be excused if the omission was the result of deficient post-conviction representation, the continuing duty of loyalty to the client demands that such an inquiry be undertaken. It would be best if experienced post-conviction counsel could be obtained to do the record review and conduct the investigation, but little about capital postconviction representation reflects best practices. Courts are reluctant to fund such work, and experienced post-conviction counsel are overworked and cannot and should not be expected to perform the work for free. Thus, in such situations counsel will simply have no alternative but to attempt to assess the quality of their previous representation-honestly and candidly, with an awareness of the possibility of self-serving or impartial judgments. ${ }^{223}$

222. 512 U.S. 849, 855 (1994) (holding that death-sentenced inmates have a right to have counsel appointed prior to filing a petition for writ of habeas corpus).

223. At the risk of over-complicating an already over-complicated set of possible scenarios, this investigation must also take place in a sufficiently timely manner to discern the existence of any additional, previously unraised claims before the statute of limitations for federal habeas petitions expires. See 28 U.S.C. $\$ 2244$ (2012) (requiring a federal petition to be filed within one year of the case becoming "final" on direct review subject to tolling during "properly filed" state 
Many readers are likely now scratching their heads and wondering who created such an arcane set of doctrines that inexorably lead to what in any other context would be considered absurd practices and results that can literally result in someone with a meritorious claim being executed. It is not a hyperbole to classify the current regime as "Kafkaesque." For the most part, fault lies with the Supreme Court. The Court's creation of a number of doctrines, e.g., procedural default, ostensibly to promote comity and federalism but clearly intended to limit the availability of federal habeas corpus to state prisoners and especially death-sentenced inmates has made habeas practice both complicated and unforgiving. ${ }^{224}$ Congress also must take its share of the blame for the habeas modifications contained in AEDPA. Numerous scholars - and even Supreme Court Justices - have commented on the statute's shoddiness, which has in turn created numerous interpretive questions courts are still sorting out almost twenty years after its enactment. ${ }^{225}$ And finally, state legislatures and courts, which have refused to appoint and compensate competent counsel in state post-conviction proceedings, also must take their share of the blame. But the purpose of this Article is not primarily to look backward and assess blame for the current "pickle" the legal community is in, but to look forward and, at least in this particular corner of the habeas imbroglio, offer some possible solutions.

One solution to the hall-of-mirrors problem created by Martinez is to take some of the pressure off defense counsel to be the only institutional actor with a responsibility to ensure that capital cases are decided fairly on the merits. ${ }^{226}$ This Article suggests that states' attorneys and federal

post-conviction proceedings). Some courts have held-nonsensically-that Martinez's equitable exception for otherwise procedurally defaulted claims is not an exception to the limitations period. See, e.g., Lambrix v. Fla. Dep't of Corr., 756 F.3d 1246, 1262 (11th Cir. 2014) ("Martinez does not alter the statutory bar against filing untimely $\S 2554$ petitions."). Furthermore, in Mayle v. Felix, the Supreme Court held that a defendant could not amend a habeas petition after the limitations period expires to include claims unrelated to those in the timely filed petition. 545 U.S. 644,650 (2005).

224. For a more detailed discussion of the Court's handiwork in this area, see John H. Blume, AEDPA: The "Hype" and the "Bite," 91 CORNELL L. REV. 259, 265-70 (2006).

225. See, e.g., LARRY W. YACKLE, FedERAL COURTS: HABEAS CORPUS 57 (2003) (“AEDPA is notorious for its poor drafting. The Act is replete with vague and ambiguous language, apparent inconsistency, and plain bad grammar."). Justice David Souter remarked that "in a world of silk purses and pigs' ears, the Act is not a silk purse of the art of statutory drafting." Lindh v. Murphy, 521 U.S. 320, 336 (1997).

226. Another partial solution beyond the scope of this Article would be to require the appointment and adequate compensation of experienced, competent counsel in state postconviction proceedings and to provide reasonable funds for investigative and expert assistance. Most states do not provide either appointment or funding, even in capital cases. Raising the overall quality of state post-conviction representation would necessarily reduce the number of viable claims of inadequate post-conviction representation. 
judges have an important role to play in this context. Bear in mind, it is a state's invocation of the affirmative defense of procedural default - in an effort to prevent a federal judge from reaching the merits of a potentially meritorious ineffective assistance of counsel claim - that creates the procedural morass this Article has described. This in turn can lead to both inefficient litigation and unjust results. Thus, in most instances, if attorneys for the state agreed - either on their own or after being "leaned on" by the court - to waive procedural default and allow the court to proceed to the merits, litigation would proceed expeditiously and without the ethical taint of potential and actual conflicts of interest. ${ }^{227}$ If the claims are not bona fide, the court will reject them.

On the other hand, if the issues not previously raised are meritorious, then there are no true "losers," except possibly those people who ascribe to the view that death sentences resulting from a trial infected with prejudicial constitutional error should be carried out. The responsibility of avoiding the types of potential conflicts of interest this Article has noted lies not solely with counsel for condemned inmates. The other systemic and repeat players - states' attorneys and judges - also must do their part. As argued above, much of the mess created by the Supreme Court resulted from its inconsistent approaches to the problem of reconciling defense counsel duties arising under the Sixth Amendment with the state rules of professional conduct. ${ }^{228}$ In cases such as Whiteside and Strickland, the Court took pains to avoid interfering with the profession's capacity to self-regulate to protect clients and serve the public interest. But when ethically conscientious defense lawyers conclude that they have a conflict under the state rules of professional conduct because their clients may have a Sixth Amendment right to a merits' review of a procedurally defaulted claim, courts should not consider this a problem of defense lawyers' making and leave it to them to muddle through. The Court cannot consistently say, as it did in Cuyler, that the federal courts rely on defense lawyers to comply with their ethical obligation to detect and avoid conflicts of interest while leaving lawyers and their clients helpless when they do raise a conflict.

227. Furthermore, these same attorneys general are often (at least partially) the cause of the alleged state procedural default. Many lawyers for the state routinely oppose state post-conviction counsel's request for funding, time to conduct adequate investigations, and production of documents and other information that could lead to the identification of potentially meritorious issues. And, in some states, lawyers for the state even write the orders denying state postconviction relief, filling those orders with erroneous procedural default determinations. Thus, in equity terms-and Martinez is at bottom an equitable doctrine - in many cases the lawyers representing the State have "unclean hands."

228. See supra Part II. 


\section{CONCLUSION}

Martinez forces courts to grapple with a problem that civil lawyers have always faced, with a significant difference. Most of the cases in Part III illustrating the prior-work conflicts problem arose in the context of legal malpractice claims asserted by clients of the law firms with a conflict. The ever-present threat of a malpractice suit has given rise to mitigating procedures, such as in-house ethics advisors who are sufficiently independent of the lawyers in their own firm to be able to give advice and take advantage of the attorney-client privilege when communicating with the lawyers who are providing the representation. ${ }^{229}$ It also alerts lawyers to the fact that they are not particularly reliable judges of the competence of their own performance. Mitigating the risk of malpractice liability has thus led to the creation of practices that serve to protect client interests in the long run. Without the threat of civil liability, however, criminal lawyers do not have the same incentive to establish procedures to ensure their independence. ${ }^{230}$ The cost of noncompliance with conflicts rules is, in effect, externalized to courts and state prosecutors. Courts will be faced with motions for substitution of counsel or the appointment of independent counsel to evaluate the performance of state post-conviction counsel; states' attorneys general will have to deal with the possibility of further delay while the conflict issue is adjudicated. Standard law-and-economics analysis suggests that these institutional actors now have an incentive to minimize the expense and disruption caused by the Martinez doctrine. ${ }^{231}$ Moreover, the Constitution may require them to work toward some kind of cooperative solution. Defense counsel cannot solve this problem on their own. Thus,

229. See Elizabeth Chambliss \& David B. Wilkins, Promoting Effective Ethical Infrastructure in Large Law Firms: A Call for Research and Reporting, 30 HOFSTRA L. REV. 691, 692 (2002) (" $[\mathrm{A}]$ necdotal evidence suggests that large law firms increasingly rely on in-house ethics advisors, firm general counsel, and other internal specialists to manage the firm's compliance with ethics and malpractice regulation.").

230. Malpractice remedies for criminal defendants are generally unavailable because of causation doctrines. As a tort (negligence) cause of action, legal malpractice requires a showing of factual, but-for causation. The position of a majority of jurisdictions, with respect to factual causation, is that showing that a different outcome would have resulted if the lawyer had not been negligent would require a showing of factual innocence. That means the defendant in the criminal action must first have the conviction set aside, on direct or collateral review, before bringing a malpractice action against the lawyer. See ReSTATEMENT (THIRD) OF THE LAw Governing LAWYERS $\S 53$, cmt. D (AM. LAW INST. 1998). A leading case is Peeler v. Hughes \& Luce, 909 S.W.2d 494, 498 (Tex. 1995) ("We therefore hold that, as a matter of law, it is the illegal conduct rather than the negligence of a convict's counsel that is the cause in fact of any injuries flowing from the conviction, unless the conviction has been overturned."). As a practical matter, this means that civil malpractice actions-as opposed to Sixth Amendment ineffectiveness claimsare greatly under-litigated.

231. See, e.g., RICHARD A. POSNER, ECONOMIC ANAl YSIS OF LAW § 6.1, at 179 (5th ed. 1998). 
this Article's tentatively hopeful conclusion to this exploration of the Martinez conundrum is that the institutional actors with a stake in procedures and outcomes will work together to ensure that credible claims of inadequate state post-conviction representation are investigated competently, that clients are fully informed and involved in the decisionmaking process, and ultimately that clients' wishes are respected. As the Court itself has repeatedly emphasized, the role of defense counsel must be understood in an institutional context; the constitutional right to effective assistance of counsel must be respected "not for its own sake, but because of the effect it has on the ability of the accused to receive a fair trial." 232 If equity requires that a defendant is guaranteed reasonably competent state post-conviction representation, then judges and prosecutors - in addition to defense counsel-share responsibility for ensuring that this right is recognized. 